\title{
RYDNO IV/47. ORGANIZACJA PRZESTRZENNA OBOZOWISK W KRZEMIENICY KULTURY JANISŁAWICKIEJ W ŚWIETLE BADAŃ FUNKCJONALNYCH, SKŁADANEK ORAZ PLANIGRAFII ZNALEZISK ARCHEOLOGICZNYCH
}

\author{
RYDNO IV/47. SPATIAL ORGANIZATION OF CAMPSITES \\ AT A FLINT CONCENTRATION AREA OF JANISŁAWICE CULTURE \\ IN THE LIGHT OF FUNCTIONAL STUDIES, REFITTINGS \\ AND PLANIGRAPHY OF ARCHAEOLOGICAL FINDS
}

\begin{abstract}
Abstrakt: Treścią artykułu są studia przestrzenno-funkcjonalne obozowisk mezolitycznych kultury janisławickiej ze stanowiska Rydno IV/47. Przeprowadzone badania traseologiczne zabytków krzemiennych (drapaczy, skrobaczy, rylca, zbrojników, półtylczaków, wiórów i odłupków łuskanych, zatępca oraz wiórów zwykłych), wyróżnionych w ramach trzech skupień, wykazały w przypadku 32 okazów obecność śladów używania. Czynności, jakie podejmowano, związane były przede wszystkim z przetwarzaniem tuszy zwierzęcej oraz obróbką drewna i roślin.
\end{abstract}

Słowa kluczowe: mezolit, Polska, Rydno, analiza przestrzenna, analiza funkcjonalna, organizacja obszarów aktywności

Abstract: The article studies Mesolithic campsites of Janisławice culture at the Rydno IV/47 site in terms of their spatial organization and functional attributes. Traseological analyses of flint artifacts (scrapers, endscrapers, burins, points, truncated blades, retouched blades and flakes, crested blades and ordinary blades) from three concentrations revealed use-wear traces in the case of 32 specimens. These traces could be attributed to activities such as processing animal carcasses and processing of plants and wood.

Keywords: Mesolithic, Poland, Rydno, spatial analysis, functional analysis, organization of activity areas

${ }^{a}$ Dr Tomasz Boroń, Ośrodek Interdyscyplinarnych Badań Archeologicznych, Instytut Archeologii i Etnologii PAN, al. Solidarności 105, 00-140 Warszawa, boron@iaepan.edu.pl, ORCID iD: https:// orcid.org/0000-0001-9831-3950.

${ }^{b}$ Dr Małgorzata Winiarska-Kabacińska, Muzeum Archeologiczne w Poznaniu, ul. Wodna 27, 61-781 Poznań, mwinkab@interia.pl, ORCID iD: https://orcid.org/0000-0001-5927-8873.

c Inż. Anna Sołodko, Urząd Miasta Stołecznego Warszawy, pl. Bankowy 3/5, 00-950 Warszawa, ORCID iD: https://orcid.org/0000-0003-3174-0784. 


\section{WSTĘP}

Stanowisko Rydno IV/47 znajduje się na obszarze dużego kompleksu osadniczego „Rydno” położonego niedaleko Skarżyska-Kamiennej (ryc. 1a). Kompleks ten zajmuje bardzo ważne miejsce na mapie osadnictwa pradziejowego ziem Polski

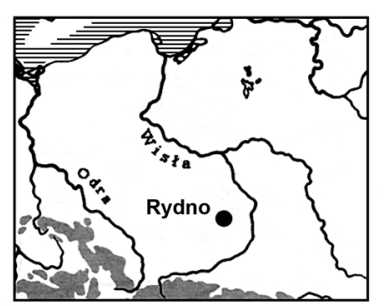

a

a

s. .+1
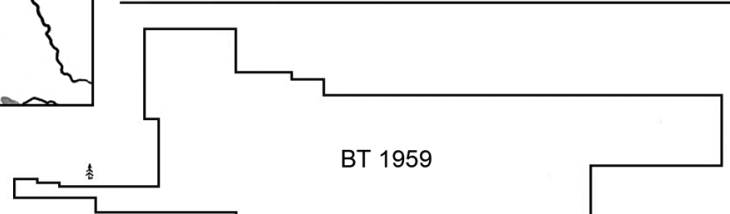

BT 1959
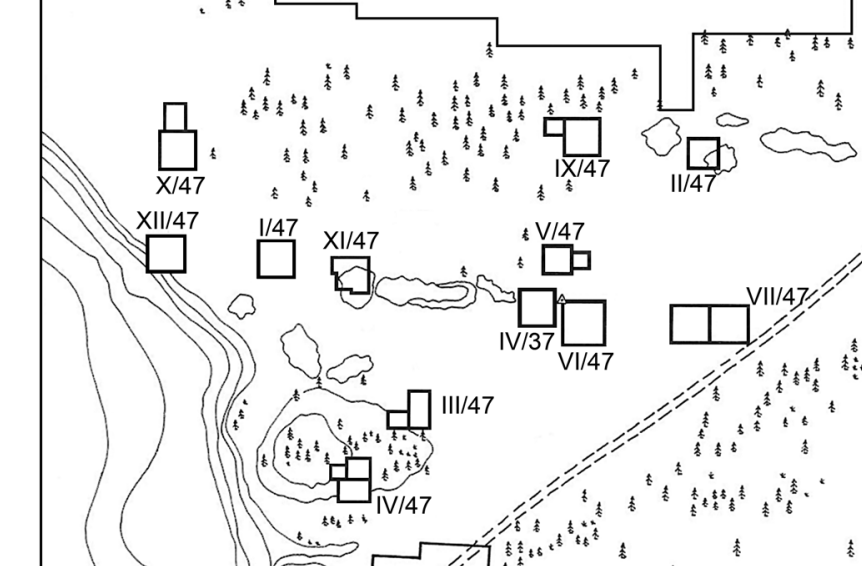

$11 / 47$
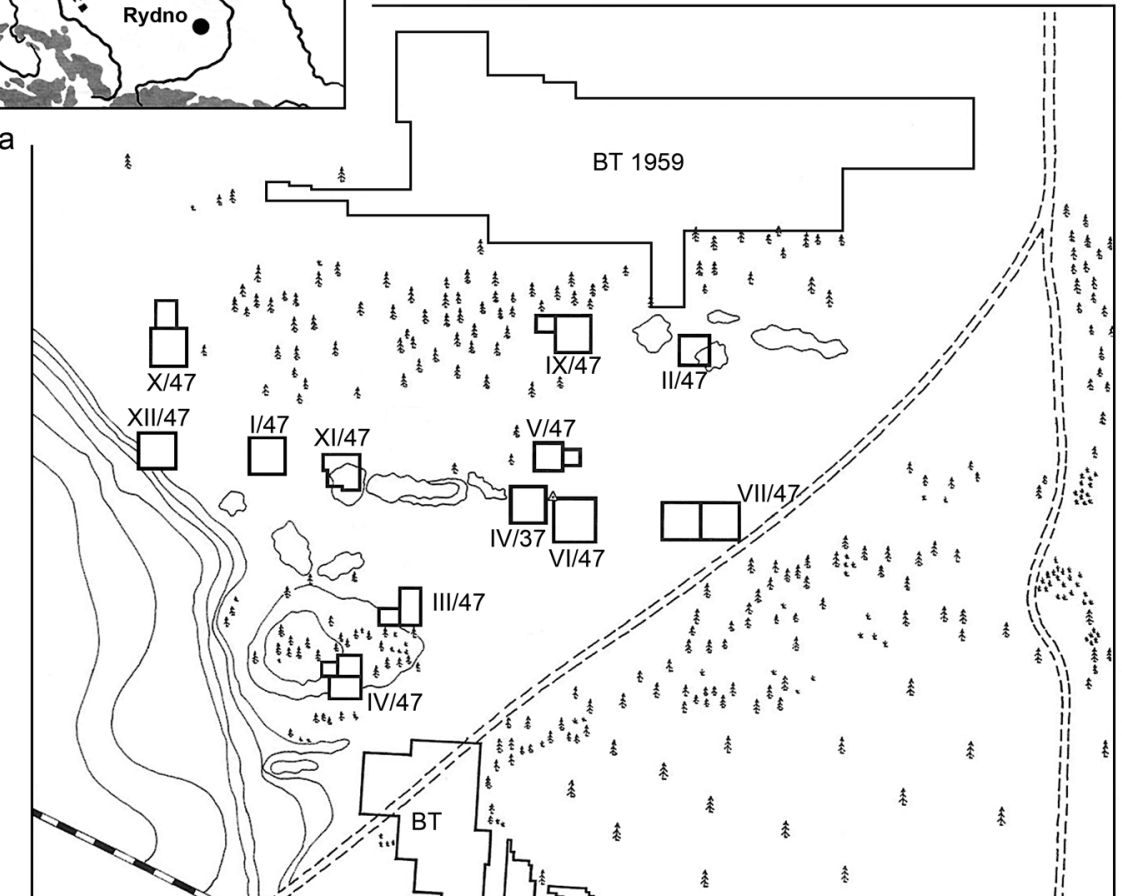

告

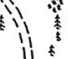

b
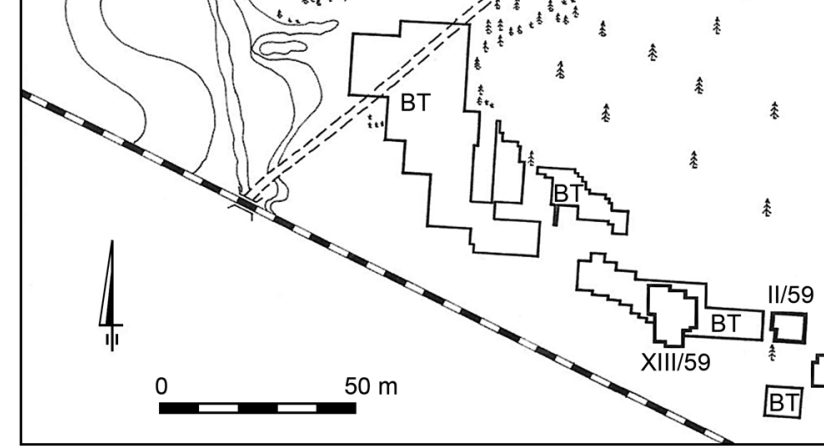

Ryc. 1. Rydno, woj. świętokrzyskie

a - położenie geograficzne Rydna; b - lokalizacja wykopów na obszarze „Pastwiska”; BT - teren systematycznego dołkowania.

Wg R. Schilda i in. 2011, s. 62, 367

Fig. 1. Rydno, Świętokrzyskie voivodeship

a - geographical location of Rydno; b - situation of trenches in the "Pastwisko" area; BT - systematic coring survey area. 


\section{INTRODUCTION}

The Rydno IV/47 site lies within the large "Rydno" complex near Skarżysko-Kamienna (Fig. 1a). The complex is an important element of the prehistoric settlement network in Polish territories in view of the number of archaeological sites of Palaeolithic and Mesolithic date grouped around a prehistoric hematite mine. Archaeological data from many seasons of fieldwork have been published extensively already (Sawicki 1935; Krukowski 1939-1948; Ginter 1965; Schild 1967; 1990; Schild et al. 1975; Schild, Królik 1981; Fiedorczuk 1992; Tomaszewski et al. 2008).

The concentration of a series of Mesolithic sites of the Janisławice culture in a small area imparts an exceptional scientific significance on the material recorded there. The finds statistics for the explored flint concentrations are hugely differentiated, from a few dozen to a few thousand pieces, and the structure of the tool inventory is also differentiated as a rule, from assemblages of mainly flake tools (Schild et al. 2011, p. 366; Boron et al. 2018) to a rather broad range of tools (Ginter 1965 , p. 7-10). The typological and technological variety of the artifacts thus lends itself to considerations of the nature and specificity of Mesolithic camps of Janisławice culture in the "Rydno" complex. Studies of spatial organization and function contribute to overall models of settlement patterns.

Trench IV (concentration X) lies in a part of the complex called "Pastwisko", one of the many specific fieldwork areas (Fig. 1b). The archaeological excavation by Stefan Krukowski in 1947 explored an area of $130 \mathrm{~m}^{2}$ (Fig. 2).

\section{MATERIALS AND METHODS}

Studies of the layout and spatial organization of campsites derive from analyses of finds distribution in the horizontal dimension (Schild 1980, pp. 79-80) and a refitting of the artifacts. The results of this approach permit the identification of specific activity zones and a determination of the spatial relations between them (Tomaszewski 1986, p. 257-273).

Planigraphic methods frequently make use of a horizontal distribution of artifacts, for example, statistical testing described in detail by Zbigniew Kobyliński (1987). Another frequently applied method calls for determining sectors and rings (Stapert [1989] 1991; 1992). With regard to the Rydno IV/47 site, the scattering of flint material and the logic behind the layout have been presented as a graphic map of point frequency per square meter using Surfer software. Effective applications of the method have been carried out by O. Grøn $(1995 ; 2003)$. The entire flint assemblage has been taken into consideration in the model projection. The results allowed for three concentrations to be distinguished: northern, central and southern (Fig. 3). Archaeological sources were divided accordingly (Table 1$).{ }^{1}$

${ }^{1}$ With the exception of a sole endscraper from the surface. 
ze względu na licznie występujące tam stanowiska archeologiczne, przede wszystkim paleolityczne i mezolityczne, otaczające prehistoryczną kopalnię hematytu. Źródła archeologiczne pozyskane w ciągu wieloletnich prac wykopaliskowych były już niejednokrotnie prezentowane w literaturze (Sawicki 1935; Krukowski 1939-1948; Ginter 1965; Schild 1967; 1990; Schild i in. 1975; Schild, Królik 1981; Fiedorczuk 1992; Tomaszewski i in. 2008).

Zgrupowanie na niewielkim obszarze szeregu stanowisk mezolitycznych kultury janisławickiej sprawia, że wartość naukowa wydobytych tam materiałów jest wyjątkowa. Wyeksplorowane krzemienice znamionuje bardzo zróżnicowana liczba znalezisk - od kilkudziesięciu do kilku tysięcy sztuk - i najczęściej różnią się one strukturą inwentarza krzemiennego - od zespołów zawierających przede wszystkim narzędzia odłupkowe (Schild i in. 2011, s. 366; Boroń i in. 2018) po zespoły obejmujące dość szerokie spectrum narzędziowe (Ginter 1965, s. 7-10). Tak różnorodne typologicznie i technologicznie zbiory zabytków stanowią niewątpliwie istotny przyczynek do rozważań nad charakterem i specyfiką obozowisk mezolitycznych kultury janisławickiej na obszarze kompleksu „Rydno”. Jednym z aspektów interpretacji modelu osadniczego są studia przestrzenno-funkcjonalne.

Wykop IV (krzemienica X) znajduje się na obszarze zwanym „Pastwisko”, który był jednym z wielu wyszczególnionych terenów badań wykopaliskowych (ryc. 1b). Prace archeologiczne były prowadzone w roku 1947 przez S. Krukowskiego. Przebadano wówczas obszar o powierzchni $130 \mathrm{~m}^{2}$ (ryc. 2).

\section{MATERIAŁY I METODY}

Studia nad rozplanowaniem i organizacją przestrzenną obozowisk bazują przede wszystkim na analizie horyzontalnej dystrybucji artefaktów (Schild 1980, s. 79-80) oraz na ich składaniu. Efekty, jakie uzyskuje się podczas stosowania tego zabiegu, umożliwiają wyróżnienie poszczególnych stref aktywności, ich identyfikację oraz określenie relacji przestrzennych pomiędzy nimi (Tomaszewski 1986, s. 257-273).

Rozrzut horyzontalny obiektów archeologicznych jest wykorzystywany w wielu metodach analiz planigraficznych. Jedną z nich są testy statystyczne szczegółowo opisane i zaprezentowane przez Z. Kobylińskiego (1987). Kolejną, dość często stosowaną metodą jest wyznaczanie sektorów i pierścieni (Stapert [1989] 1991; 1992).

Ryc. 2. Rydno IV/47. Planigrafia rozrzutu przestrzennego krzemieni

a - rdzenie; b - drapacze; c - skrobacze; d - półtylczaki; e - zbrojniki typu Wieliszew; f - rylce; g - trapezy; $\mathrm{h}$ - nieokreślone formy mikrolitów; $\mathrm{i}$ - wióry łuskane; $\mathrm{j}$ - odłupki łuskane; $\mathrm{k}$ - inne; 1 - rylcowce; 1 - krzemienie; $\mathrm{m}$ - przepalone kości; $\mathrm{n}$ - kamienie.

Wg R. Schilda i in. 2011, s. 62, 367, z uzupełnieniami T. Boronia

Fig. 2. Rydno IV/47. Planigraphy of the distribution of flint finds

$\mathrm{a}$ - cores; $\mathrm{b}$ - endscrapers; c - scrapers; $\mathrm{d}$ - truncated blades; $\mathrm{e}$ - Wieliszew points; $\mathrm{f}$ - burins; $\mathrm{g}$ - trapezes; $\mathrm{h}$ - indeterminate microliths; $\mathrm{i}$ - retouched blades; $\mathrm{j}$ - retouched flakes; $\mathrm{k}$ - other; 1 - microburins; $\mathrm{l}$ - flints; $\mathrm{m}$ - burnt bone; $\mathrm{n}$ - stones.

After R. Schild et al. 2011, p. 62, 367, amended by T. Boroń 


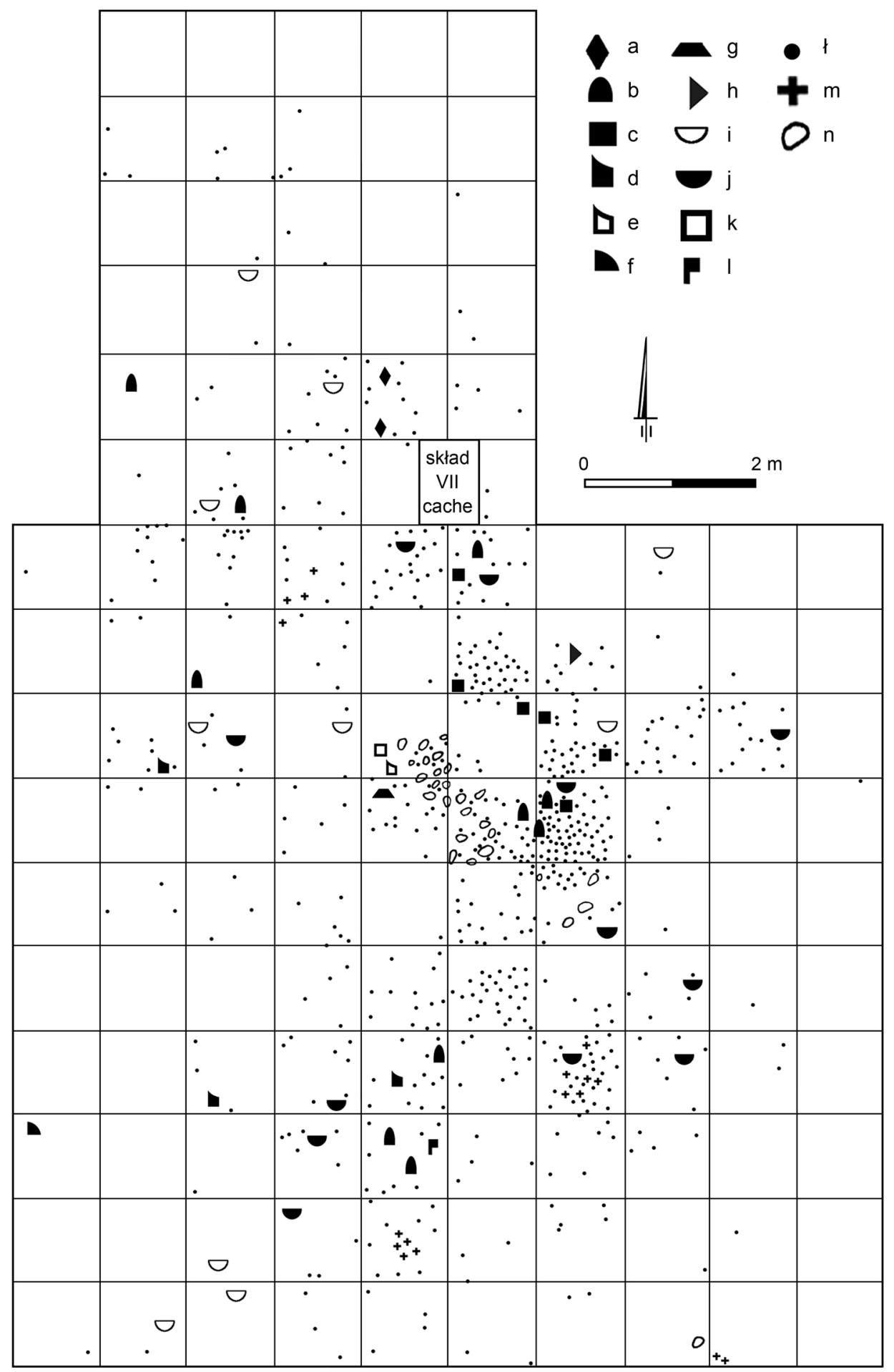


Tabela 1. Zestawienie typów narzędzi w poszczególnych skupieniach

\begin{tabular}{|l|c|c|c|}
\hline \multicolumn{1}{|c|}{ Kategoria inwentarza } & $\begin{array}{c}\text { Skupienie } \\
\text { północne }\end{array}$ & $\begin{array}{c}\text { Skupienie } \\
\text { centralne }\end{array}$ & $\begin{array}{c}\text { Skupienie } \\
\text { południowe }\end{array}$ \\
\hline \hline rdzenie & 2 & & \\
\hline drapacze & 3 & 4 & 3 \\
\hline skrobacze & 1 & 5 & \\
\hline rylce & & & 1 \\
\hline półtylczaki & & 1 & 2 \\
\hline zbrojniki typu Wieliszew & & 1 & \\
\hline trapezy & & 1 & \\
\hline fragmenty nieokreślonych mikrolitów & 3 & 4 & 3 \\
\hline wióry łuskane & 2 & 4 & 6 \\
\hline odłupki łuskane & & & 1 \\
\hline rylcowce & & 1 & \\
\hline inne & & & \\
\hline
\end{tabular}

Natomiast w przypadku stanowiska Rydno IV/47 dyspersja materiału krzemiennego i uchwycenie logiczności jego rozplanowania zostały wyrażone za pomocą graficznej mapy frekwencji punktów w każdym metrze kwadratowym za pomocą programu Surfer. Metoda ta jest stosowana z powodzeniem przez O. Grøna (1995; 2003). W projekcji modelu uwzględniono całość materiału krzemiennego. Stosownie do uzyskanych wyników wydzielono trzy skupienia: północne, centralne oraz południowe (ryc. 3), i tak też podzielono źródła archeologiczne (tabela 1)1.

Skupienie północne zawiera rdzenie (Schild i in. 2011, s.353), półsurowiec odłupkowy i wiórowy oraz narzędzia, w tym skrobacze, drapacze, odłupki i wióry łuskane (ryc. 4). Jego powierzchnia, uwzględniając wyraźne granice występowania materiału, wynosi około $12-13 \mathrm{~m}^{2}$. Krzemienie, jak również narzędzia, były dość równomiernie rozproszone ${ }^{2}$.

Skupienie centralne charakteryzuje się zdecydowanie największą liczbą znalezisk, których wyraźne zgrupowanie obejmuje około 10-11 $\mathrm{m}^{2}$. Odnotowano tutaj znacznie bogatsze zróżnicowanie typów narzędzi niż w obydwu pozostałych skupieniach. Poza wiórami i odłupkami łuskanymi wyszczególniono także drapacze, skrobacze, półtylczaki, mikrolity (trapez, zbrojnik typu Wieliszew, nieokreślony fragment mikrolitu) oraz „inne” (ryc. 5; 6). Dystrybucja przestrzenna narzędzi pokazuje, że koncentrują się one na dwóch oddzielnych obszarach. Pierwszy, obejmujący

${ }^{1} \mathrm{~W}$ opracowaniu nie uwzględniono jednego drapacza pozyskanego z powierzchni.

${ }^{2}$ W skupieniu północnym pominięto skład VII, zawierający rdzenie i obłupnie. Został on szczegółowo opisany w publikacji Rydna (Schild i in. 2011, s. 89-91). Skład stanowi odrębny obiekt archeologiczny o zamkniętych przestrzennie granicach, co utrudnia określenie jego relacji z pozostałym materiałem krzemiennym. 
Table 1. Tool types in particular scatters

\begin{tabular}{|l|c|c|c|}
\hline \multicolumn{1}{|c|}{ Inventory category } & $\begin{array}{c}\text { Northern } \\
\text { scatter }\end{array}$ & $\begin{array}{c}\text { Central } \\
\text { scatter }\end{array}$ & $\begin{array}{c}\text { Southern } \\
\text { scatter }\end{array}$ \\
\hline cores & 2 & & \\
\hline endscrapers & 3 & 4 & 3 \\
\hline scrapers & 1 & 5 & \\
\hline burins & & & 1 \\
\hline truncated blades & & 1 & 2 \\
\hline Wieliszew points & & 1 & \\
\hline trapezes & & 1 & \\
\hline indeterminate microlith fragments & 3 & 4 & 3 \\
\hline retouched blades & 2 & 4 & 6 \\
\hline retouched flakes & & & 1 \\
\hline microburins & & 1 & \\
\hline other & & & \\
\hline
\end{tabular}

The northern concentration yielded cores (Schild et al. 2011, p. 353), flake and blade semi-products and tools, the latter including scrapers, endscrapers retouched blades and flakes (Fig. 4). The surface area of this concentration within distinct boundaries of the occurrence of finds, is about $12-13 \mathrm{~m}^{2}$. Both flints and tools were scattered quite evenly. ${ }^{2}$

The central concentration was the most numerous in terms of finds, which were grouped very distinctly on an area of about $10-11 \mathrm{~m}^{2}$. The range of tool types recorded here was much more extensive than at the other two concentrations. Retouched flakes and blades were accompanied here by endscrapers, scrapers, truncated pieces, microliths (trapezes, Wieliszew points, unidentified fragment) and others (Figs 5; 6). A spatial distribution analysis of the tools showed that they were concentrated in two different areas. The first, including practically all products, corresponded to the sector of greatest accumulation of flint, whereas the second was situated about $2 \mathrm{~m}$ to the west of the first.

The southern concentration was relatively the largest in area, counting about $18-19 \mathrm{~m}^{2}$. The products described there included retouched flakes and blades, endscrapers, truncated pieces, burins and waste from tool production (microburins) (Fig. 7). Tools were distributed rather evenly throughout the concentration, but there seem to have been small groupings of products of the same kind: retouched flakes on the eastern fringe of the concentration and retouched blades in the southern part of the feature.

${ }^{2}$ Set VII containing cores and pre-cores was not included in the northern concentration. It was described in detail in the site publication (Schild et al. 2011, pp. 89-91). The set formed a separate archaeological feature with spatially clear boundaries, making it difficult to determine its relation to the other flint material. 


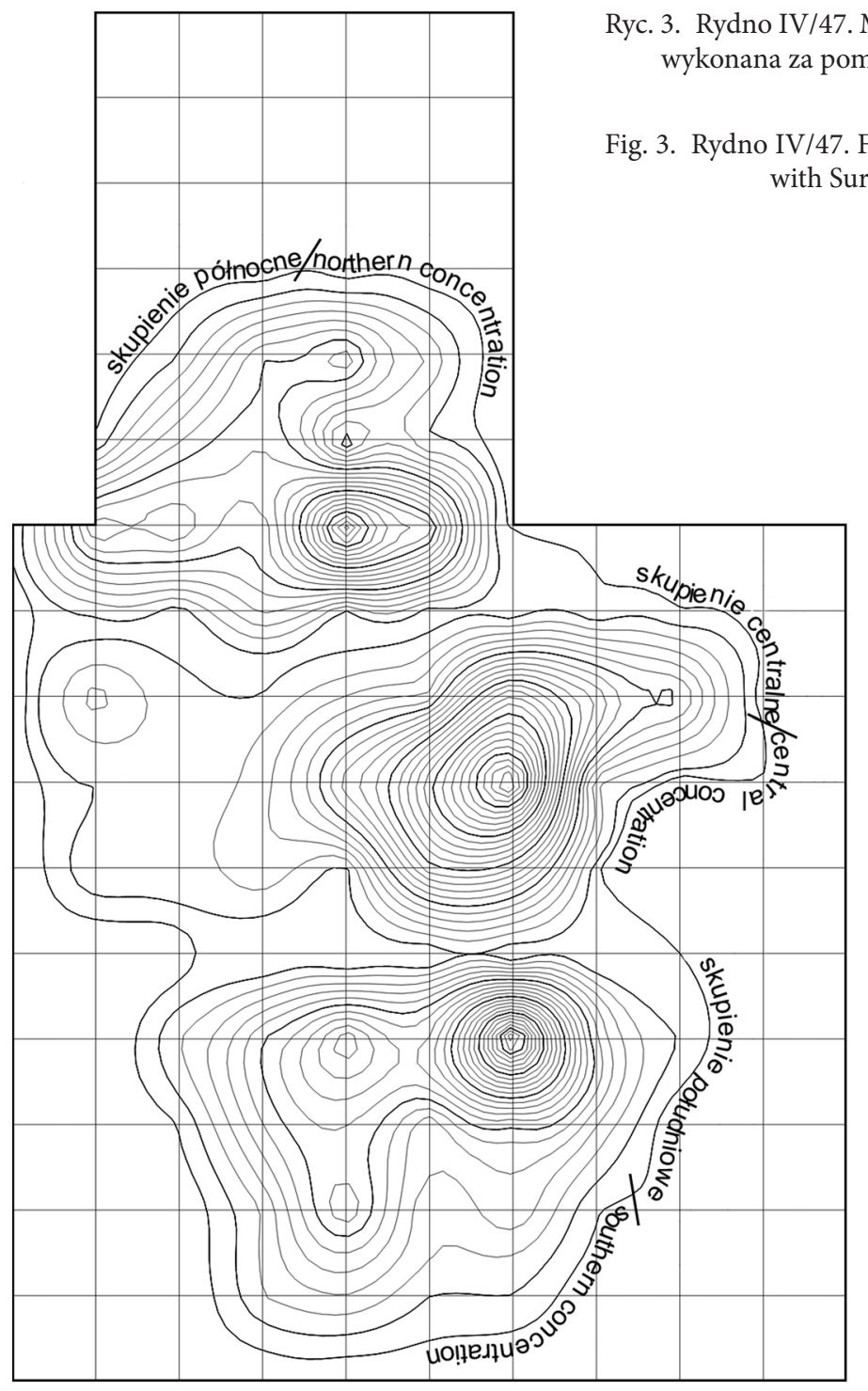

bez mała prawie wszystkie wyroby, koresponduje z sektorem największego nasycenia krzemieniami, natomiast drugi oddalony jest około $2 \mathrm{~m}$ w kierunku zachodnim.

Skupienie południowe ma relatywnie największą powierzchnię, wynoszącą około $18-19 \mathrm{~m}^{2}$. Zestaw wyrobów, jaki tam wyodrębniono, zawiera odłupki i wióry łuskane, drapacze, półtylczaki, rylce oraz odpadki z produkcji narzędzi (rylcowce) (ryc. 7). Narzędzia są dość równomiernie rozproszone na obszarze całego skupienia, można jednakże wyróżnić niewielkie rejony zgrupowań wyrobów tego samego typu - odłupków łuskanych na skraju skupienia od strony wschodniej oraz wiórów łuskanych w strefie południowej. 

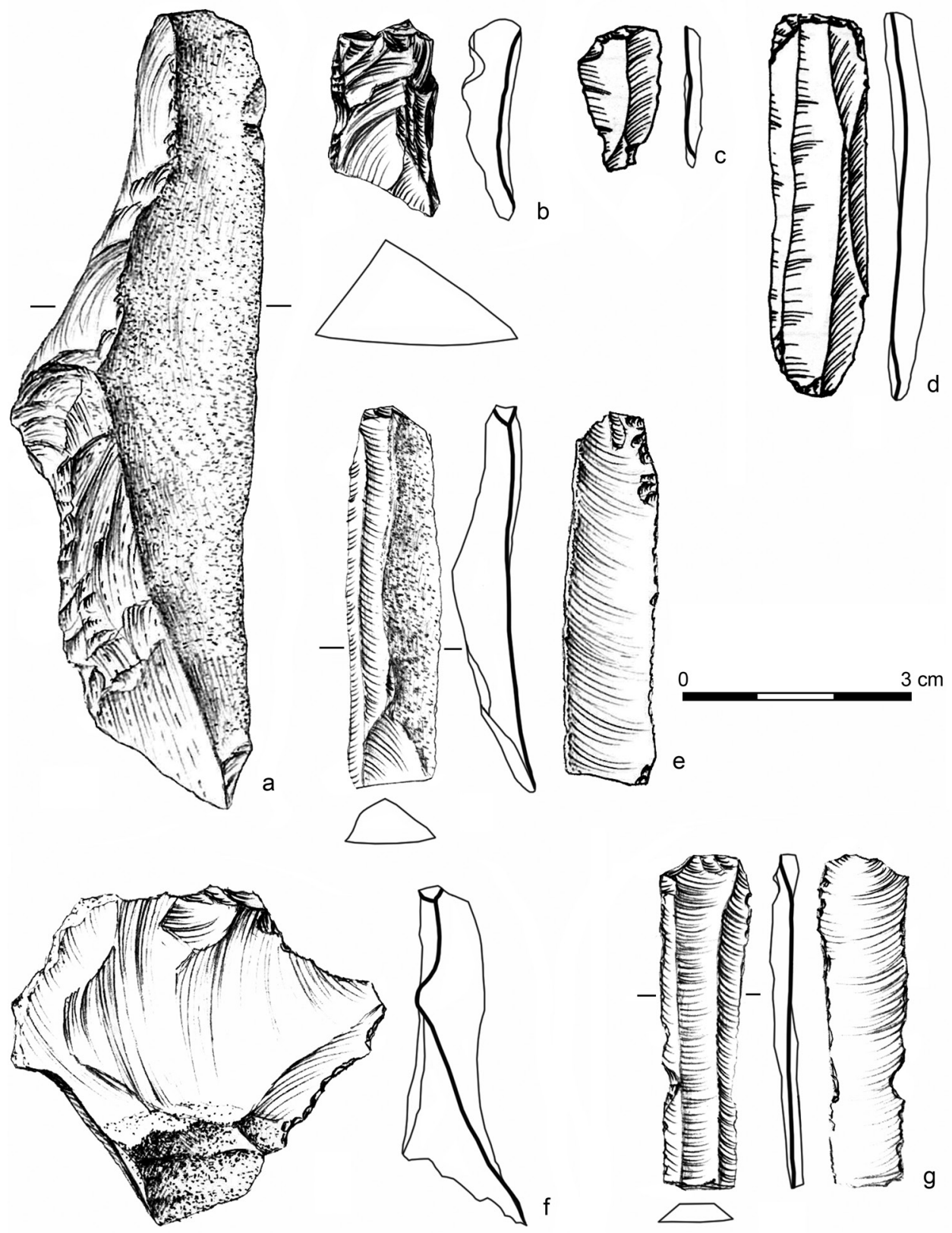

Ryc. 4. Rydno IV/47. Skupienie północne a - zatępiec; b-g - narzędzia.

Rys. I. Niewiadomska, E. Gumińska

Fig. 4. Rydno IV/47. Northern scatter a - crested blade; b-g - tools. 

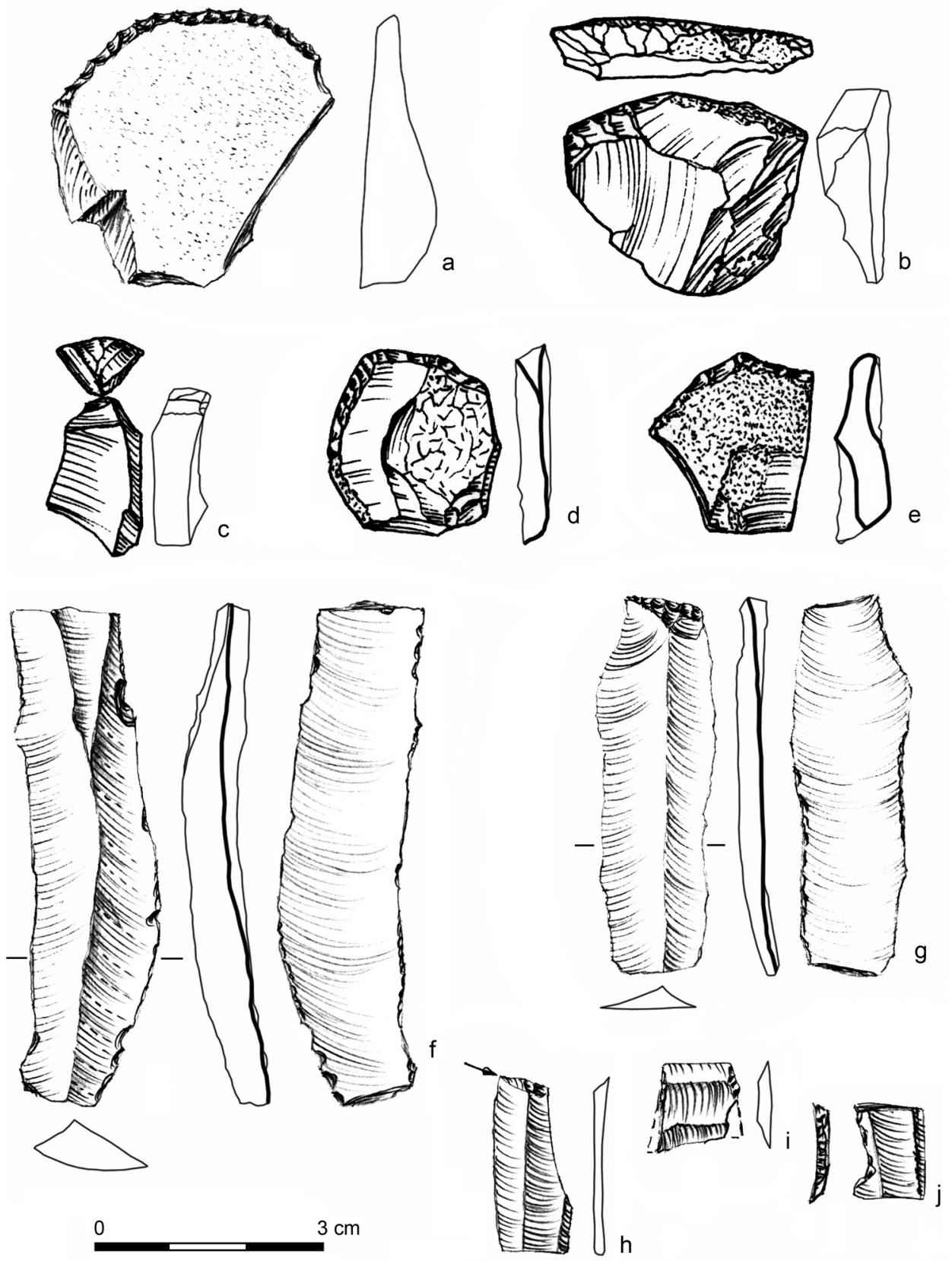

0

$3 \mathrm{~cm}$

$\mathrm{h}$

Ryc. 5. Rydno IV/47. Skupienie centralne $a-j$ - narzędzia.

Rys. I. Niewiadomska, E. Gumińska

Fig. 5. Rydno IV/47. Central scatter

$\mathrm{a}-\mathrm{j}$ - tools.

Drawing I. Niewiadomska, E. Gumińska 

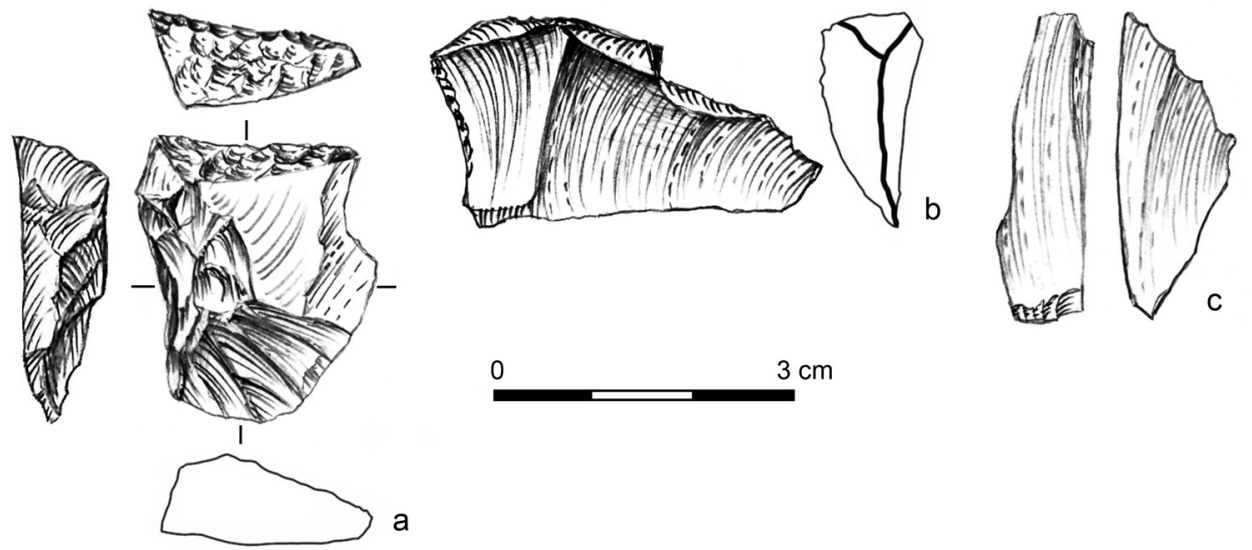

Ryc. 6. Rydno IV/47. Skupienie centralne a-c - narzędzia.

Rys. E. Gumińska

Fig. 6. Rydno IV/47. Central scatter a-c - tools.

Drawing E. Gumińska

\section{RESULTS OF A FUNCTIONAL ANALYSIS OF SELECTED FLINT ARTIFACTS}

Traseological studies were carried out on tools and a sample of semi-products, that is, 32 unretouched blades, the purpose being to trace any evidence of use-wear that could indicate function. The material was analyzed respectively for the three distinguished concentrations. The method of observation and subsequent analysis has been described in the literature (Boron et al. 2018) and depends on microscopic observation using stereoscope and metallographic microscopes at magnifications of $6.3 \times$ to $500 \times$.

Numerous post-depositional transformations of the artifacts selected for study, kept in storage for more than 60 years after the excavation, added to the difficulty of microscopic observation.

\subsection{MATERIAL}

S outhern concentration. 24 specimens chosen for study. Three endscrapers bore use-wear traces (Fig. $8 \mathrm{a}-\mathrm{c}$ ). ${ }^{3}$ These traces were probably the effect of scraping animal hides. In one case, a blade refitted with an endscraper yielded traces that could be linked to a hafting (Fig. 8a). The tip of a burin (Fig. 8e) showed shining that could be due to carving in bone (Fig. 9a). No use-wear traces were noted on two truncated pieces. One retouched blade was used apparently for animal carcass

\footnotetext{
${ }^{3}$ Graphic processing of the figures by A. Sołodko.
} 

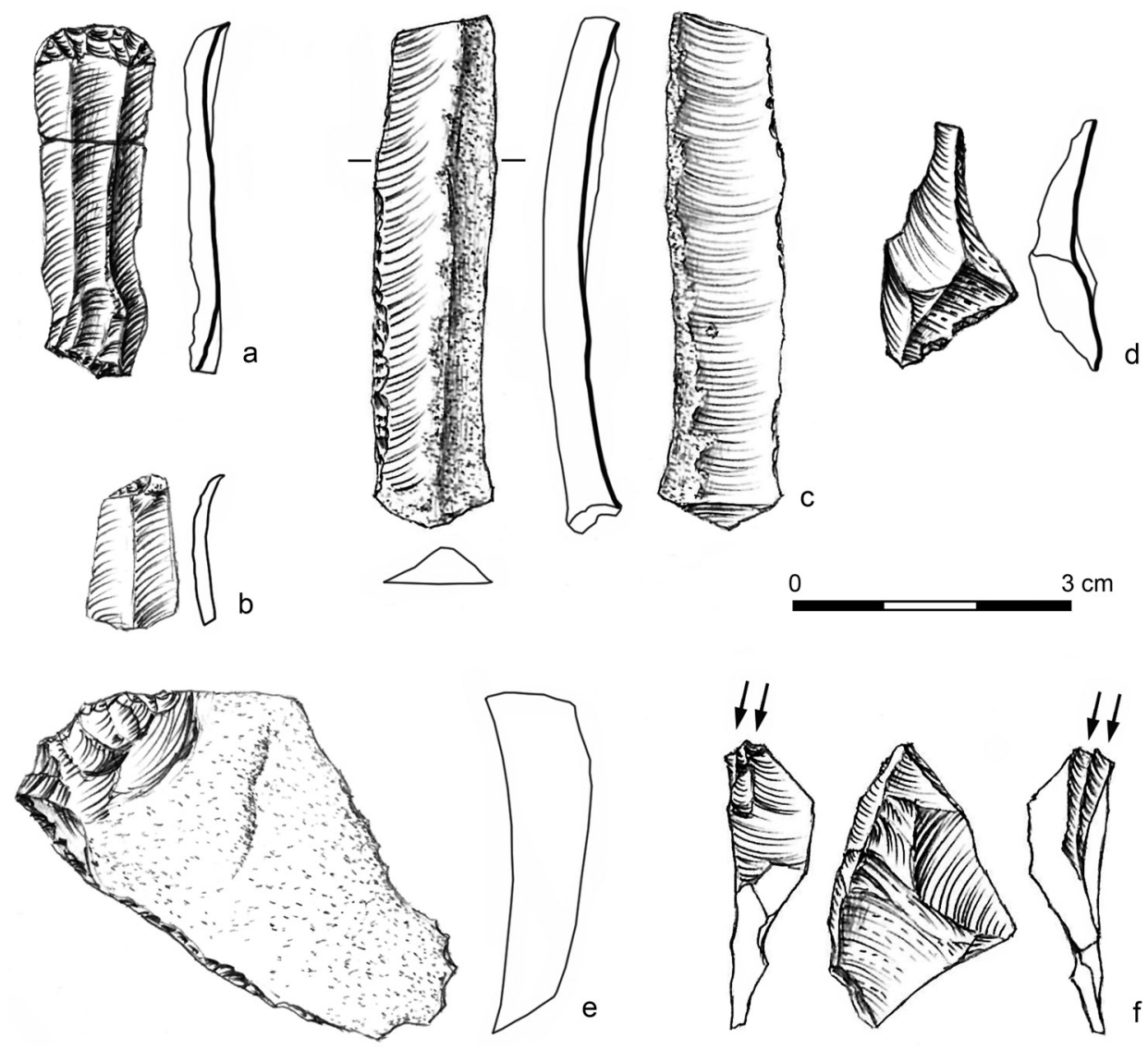

Ryc. 7. Rydno IV/47. Skupienie południowe a-f - narzędzia.

Fig. 7. Rydno IV/47. Southern scatter a-f - tools.

Rys. E. Gumińska

Drawing E. Gumińska

\section{WYNIKI ANALIZY FUNKCJONALNEJ WYBRANYCH ZABYTKÓW KRZEMIENNYCH}

Badaniami traseologicznymi objęto narzędzia oraz próbę półsurowca, tj. 32 wióry bez retuszu. Celem podjętych badań było stwierdzenie, czy przedmioty miały jakiekolwiek przekształcenia wskazujące na ich używanie i jaką pełniły funkcję. Materiał analizowano w ramach wyróżnionych skupisk: południowego, północnego i centralnego. Do prowadzenia obserwacji i ich późniejszej analizy zastosowano metodę opisaną już wcześniej (Boroń i in. 2018), w której podstawowym elementem są obserwacje mikroskopowe, przy wykorzystaniu mikroskopów stereoskopowego i metalograficznego, przy zastosowaniu powiększeń od 6,3× do 500×. 

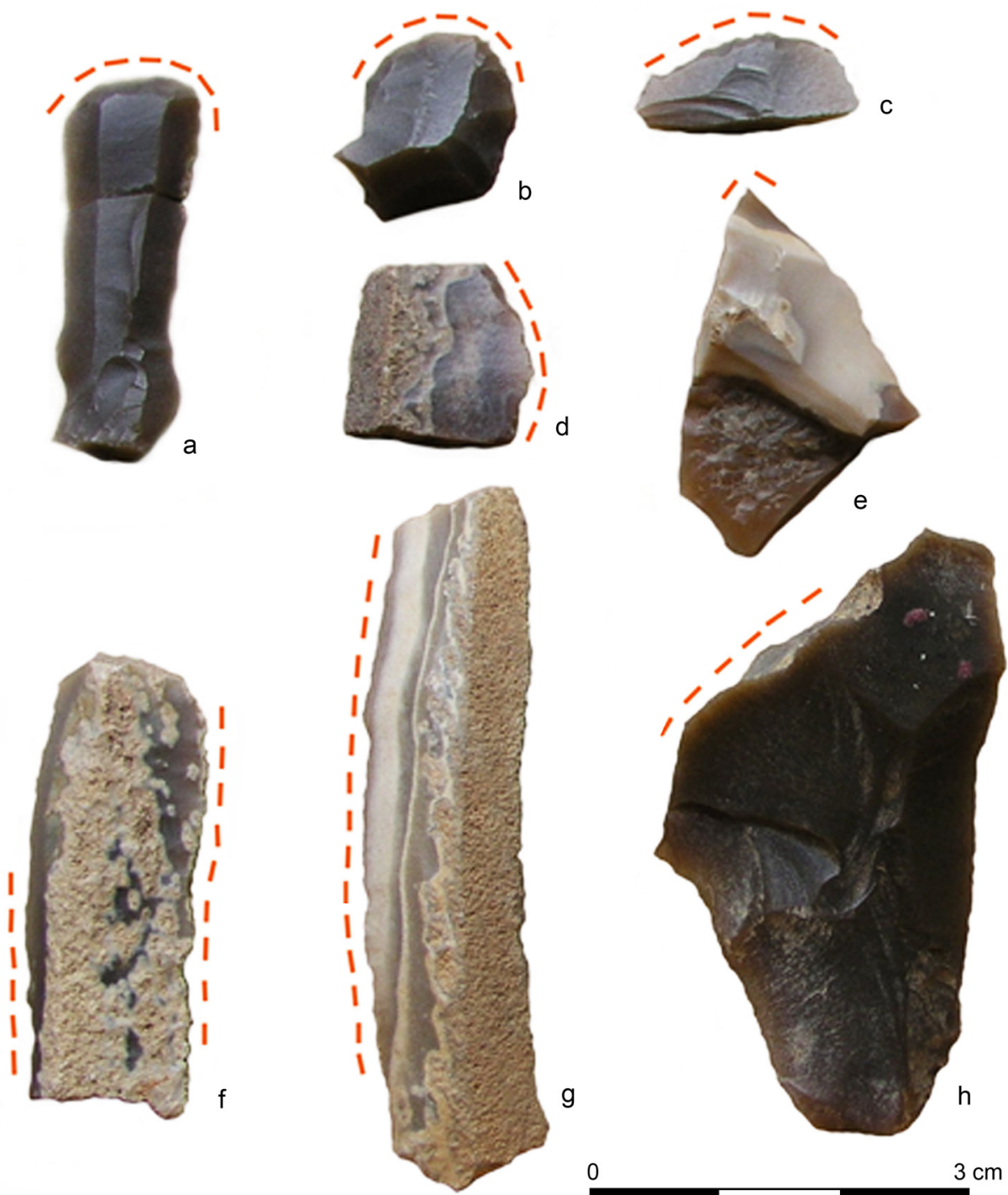

Ryc. 8. Rydno IV/47. Skupienie południowe a-h - krzemienie ze śladami używania; ----- - ślady używania.

Fot. M. Winiarska-Kabacińska

Fig. 8. Rydno IV/47. Southern scatter a-h - flints with traces of use; ----- - use-wear traces.

Photo M. Winiarska-Kabacińska

butchering (Fig. 8f), another for cutting plants (Figs. 8g; 9b), the third and last for processing wood (Fig. 8d). Of the six retouched flakes, one (Fig. 8h) demonstrated evidence of processing an unidentified raw material. Ordinary blades (eight pieces) did not bear any use-wear changes. 

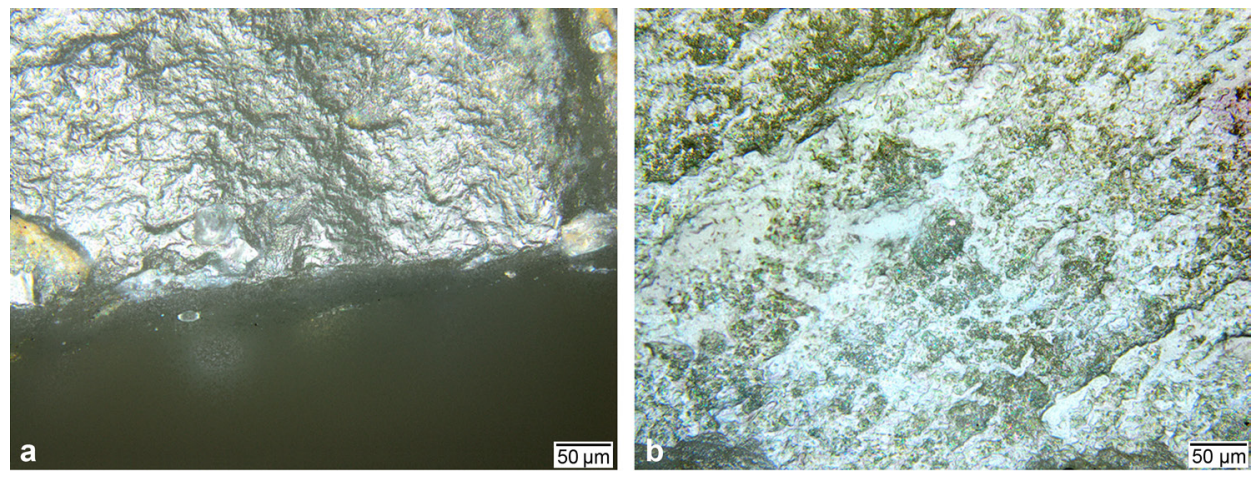

Ryc. 9. Rydno IV/47. Skupienie południowe a - zdjęcie mikroskopowe: rylec (ryc. 8e), rycie w kości; b - zdjęcie mikroskopowe: wiór łuskany (ryc. 8g), cięcie roślin.

Fot. M. Winiarska-Kabacińska

Fig. 9. Rydno IV/47. Southern scatter

a - microscopic photo: burin (Fig. 8e), carving in bone; b - microscopic photo: retouched blade (Fig. $8 \mathrm{~g}$ ), cutting organic plants.

Photo M. Winiarska-Kabacińska

Zabytki poddane badaniom, pochodzące z badań wykopaliskowych sprzed ponad sześćdziesięciu lat, miały liczne przekształcenia postdepozycyjne, co utrudniło prowadzenie obserwacji.

\subsection{MATERIAŁY}

Skupie ni e południowe. Z tego skupienia przebadano 24 okazy. Wszystkie trzy analizowane drapacze nosiły ślady o charakterze użytkowym (ryc. 8a-c) ${ }^{3}$. Prawdopodobnie powstały w wyniku skrobania świeżej skóry. W jednym przypadku, na wiórze będącym częścią składanki z drapaczem, zarejestrowano ślady przypuszczalnie pochodzące od oprawy (ryc. 8a). Na samym wierzchołku rylca (ryc. 8e) stwierdzono ślady wyświecenia będące rezultatem rycia w kości (ryc. 9a). W przypadku dwóch półtylczaków nie odnotowano występowania przekształceń o charakterze użytkowym. Jeden wiór łuskany użyto do rozdziału tuszy zwierzęcej (ryc. 8f), kolejny do cięcia roślin (ryc. 8g; 9b), natomiast ostatni do obróbki drewna (ryc. 8d). Spośród sześciu badanych odłupków łuskanych jeden (ryc. 8h) wykazał obecność cech wskazujących na obróbkę nieokreślonego surowca. Wióry zwykłe (8 sztuk) nie miały czytelnych przekształceń o charakterze użytkowym.

Skupienie północne. Obserwacjom poddano 21 okazów. Jeden spośród trzech analizowanych drapaczy był użyty do obróbki nieokreślonego surowca (ryc. 10a), kolejny do skrobania skóry (ryc. 10b; 11a), przy czym ślady obecne na krawędziach bocznych powstały od oprawy, w jakiej było osadzone narzędzie. Trzeci drapacz nie wykazał czytelnych śladów używania. Skrobacz (ryc. 10c) wykorzystano

\footnotetext{
${ }^{3}$ Graficzną obróbkę rycin wykonała A. Sołodko.
} 

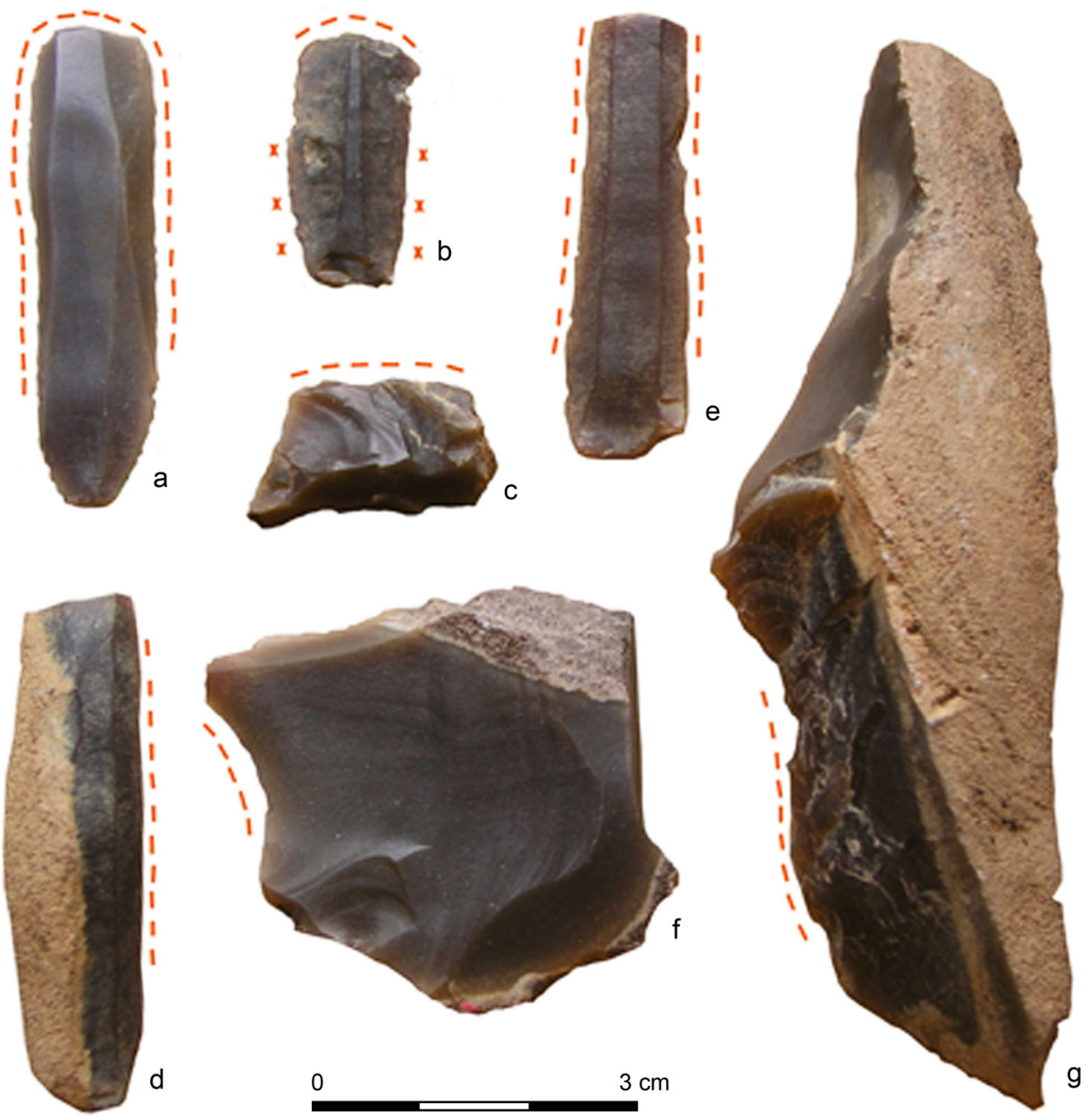

Ryc. 10. Rydno IV/47. Skupienie północne a-g - krzemienie ze śladami używania; ----- - ślady używania; xxx - oprawa.

Fot. M. Winiarska-Kabacińska

Fig. 10. Rydno IV/47. Northern scatter

a-g - flints with traces of use; ----- - use-wear traces; $\mathrm{xxx} \mathrm{-} \mathrm{hafting.}$

Photo M. Winiarska-Kabacińska

Norther n concentration. 21 specimens were studied. One of the three examined endscrapers had been used for processing an unidentified raw material (Fig. 10a), another for scraping animal hide (Figs. 10b; 11a); traces on the lateral surfaces were from the hafting of the tool. The third endscraper bore no use-wear traces. A scraper (Fig. 10c) had been used to scrape wood, a retouched blade (Fig. 10e) for cutting antler, yet another for a soft raw material (Fig. 10d), while the third showed no use-wear evidence. One of two retouched flakes (Fig. 10f) was for scraping plants, but the recorded traces do not suggest intensive use. The 

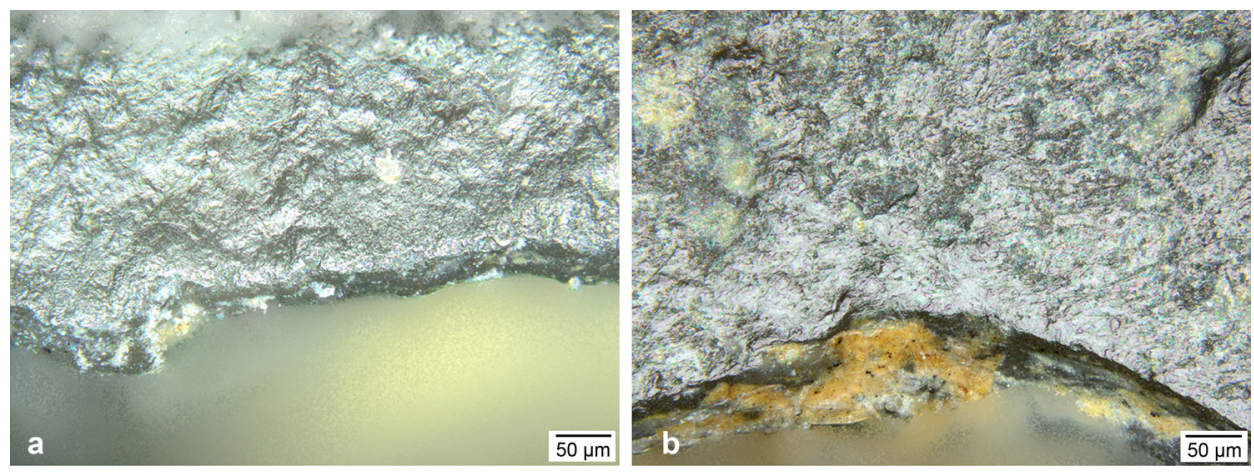

Ryc. 11. Rydno IV/47. Skupienie północne

a - zdjęcie mikroskopowe: drapacz (ryc. 10b), skrobanie skóry; b - zdjęcie mikroskopowe: zatępiec (ryc. 10g), skrobanie kości.

Fot. M. Winiarska-Kabacińska

Fig. 11. Rydno IV/47. Northern scatter

a - microscopic photo: endscraper (Fig. 10b), scraping animal hide; b - microscopic photo: crested blade (Fig. 10g), scraping bone.

Photo M. Winiarska-Kabacińska

do skrobania drewna, jeden wiór łuskany (ryc. 10e) do cięcia poroża, kolejny do obróbki miękkiego surowca (ryc.10d), natomiast w przypadku trzeciego wióra łuskanego nie stwierdzono obecności śladów używania. Jeden z dwóch badanych odłupków łuskanych (ryc. 10f) był używany do skrobania roślin, a zarejestrowane ślady nie są intensywne. Z kolei intensywnie używano zatępca (ryc. $10 \mathrm{~g}$ ), w przypadku którego przekształcenia powstałe $\mathrm{w}$ rezultacie skrobania kości $\mathrm{z}$ dodatkiem mięsa widoczne są na części krawędzi (ryc. 11b). W grupie 11 wiórów zwykłych dwa okazy były wykorzystywane do obróbki roślin.

Skupienie centralne. Z tego skupienia przebadano największą liczbę okazów (35 sztuk). Dwa drapacze (ryc. 12a, b; 13a) były wykorzystywane do skrobania skóry, w przypadku kolejnych dwóch nie stwierdzono obecności jednoznacznych śladów używania. Wśród analizowanych pięciu skrobaczy wydzielono jeden (ryc. 12c), na którym wystąpiły ślady skrobania świeżej skóry, na dwóch - skrobania drewna (ryc. 12d, e), na pozostałych natomiast nie zauważono śladów używania. W przypadku półtylczaka, nieokreślonego fragmentu mikrolitu oraz narzędzia określanego jako „inne” nie zaobserwowano przekształceń wskazujących na ich używanie. Natomiast dwa analizowane zbrojniki stanowily elementy broni miotanej. Jednym z nich był przegrzany trapez (ryc. 12j), z niewielkimi uszkodzeniami widocznymi na jednej z bocznej krawędzi, drugim zbrojnik typu Wieliszew (ryc. 12k). Spośród czterech badanych wiórów łuskanych, jeden (ryc. 12g) był używany do cięcia poroża, a kolejny (ryc. 12h) do cięcia twardego surowca. Natomiast $\mathrm{z}$ analizowanych czterech odłupków łuskanych jednym skrobano kość (ryc. 12f; 13b), a na drugim (ryc. 12i) odkryto ślady pochodzące od obróbki bliżej nieokreślonego surowca. Przedmiotem obserwacji było także 13 wiórów zwykłych, z których jeden okaz nosił ślady cięcia roślin, a trzy obróbki miękkiego surowca. 


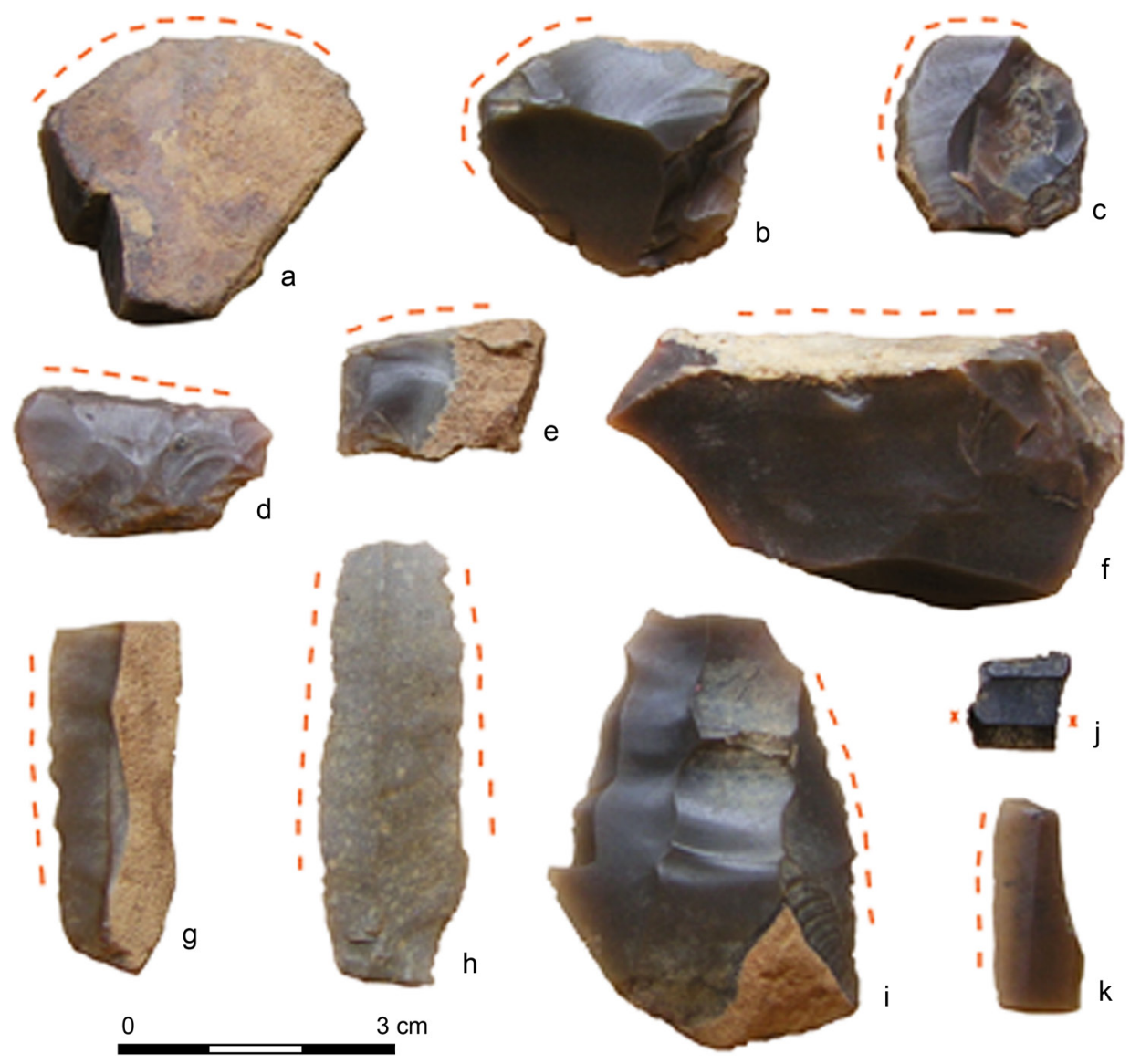

Ryc. 12. Rydno IV/47. Skupienie centralne a-k - krzemienie ze śladami używania; ----- - ślady używania; xxx - oprawa.

Fot. M. Winiarska-Kabacińska

Fig. 12. Rydno IV/47. Central scatter $\mathrm{a}-\mathrm{k}$ - flints with traces of use; ----- - use-wear traces; $\mathrm{xxx}$ - hafting.

Photo M. Winiarska-Kabacińska

opposite was the case of a crested blade (Fig. 10g), which was used intensively for scraping a meaty bone as indicated by the traces on part of the edge (Fig. 11b). Of the 11 regular blades, two specimens were applied for plant processing activities.

$\mathrm{C}$ entral con ce ntration. The largest number of specimens studied came from this assemblage (35 pieces). Two endscrapers (Figs. 12a, b; 13a) were used for scraping animal hides; in two other cases there were no evident use-wear traces. Of five examined scrapers, one (Fig. 12c) had been used on fresh animal hide, two for scraping wood (Fig. 12d, e), the others appear not to have been used. No use-wear traces could be observed on a truncated piece, unidentified microlithic fragment and a tool referred to as "other". The two points came from throwing weapons. One 

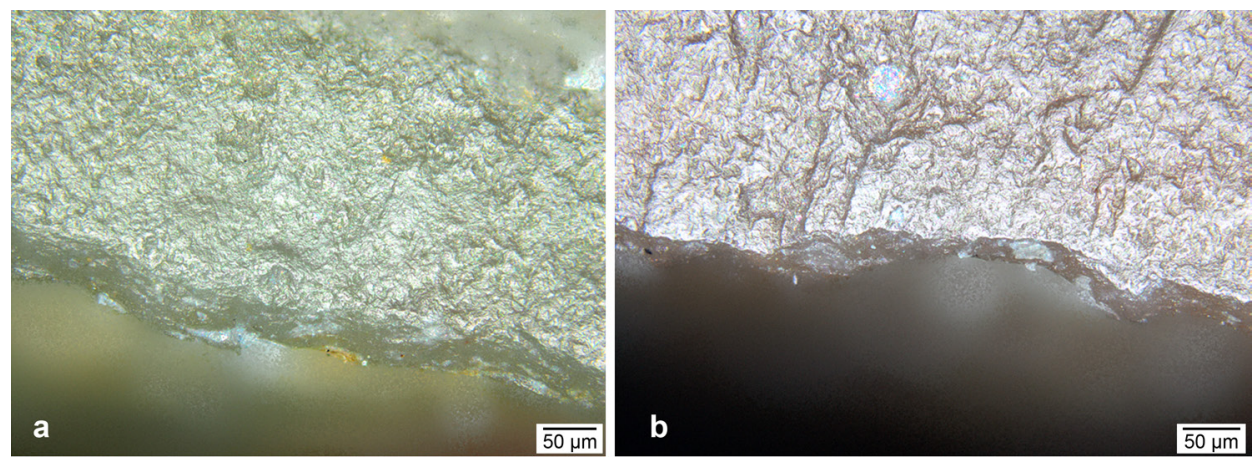

Ryc. 13. Rydno IV/47. Skupienie centralne

a - zdjęcie mikroskopowe: drapacz (ryc. 12b), skrobanie skóry; b - zdjęcie mikroskopowe: odłupek łuskany (ryc. 12f), skrobanie kości.

Fot. M. Winiarska-Kabacińska

Fig. 13. Rydno IV/47. Central scatter

$\mathrm{a}$ - microscopic photo: endscraper (Fig. 12b), scraping animal hide; $\mathrm{b}$ - microscopic photo: retouched flake (Fig. 12f), scraping bone.

Photo M. Winiarska-Kabacińska

Czynności, jakie podejmowano w obrębie wyróżnionych skupisk, związane były przede wszystkim z przetwarzaniem tuszy zwierzęcej oraz obróbką drewna i roślin. Narzędzia, jakimi się posługiwano, na ogół nie były intensywnie używane. Charakter przekształceń zarejestrowanych na drapiskach wskazuje na skrobanie świeżej skóry. Także narzędzia, na krawędziach których znajdują się ślady powstałe w wyniku obróbki kości, można byłoby wiązać z procesem rozdziału tuszy zwierzęcej. Pojedyncze okazy z zarejestrowanymi śladami cięcia poroża są pozostałością po incydentalnym podjęciu tego typu czynności, a nie są związane z obróbką tego surowca.

\section{ROZPLANOWANIE STREF AKTYWNOŚCI}

W trakcie prac gabinetowych złożono kilkanaście bloków liczących od dwóch do pięciu elementów. Najczęściej dopasowano pary odłupków lub świeżaków. Jedynie trzy bloki ilustrują dłuższe sekwencje rdzeniowania. Pierwszy składa się z trzech odłupków i zatępca, drugi z zatępca, drapacza, odłupka łuskanego oraz dwóch surowych odłupków, zaś trzeci z odłupka łuskanego i trzech świeżaków ${ }^{4}$.

Skupienie północne. Przestrzenny rozrzut odłupków oraz wiórów pokazuje, że gromadzą się one przede wszystkim w strefie południowej skupienia (ryc. 14). Znajdowały się tam również wszystkie świeżaki. Dopasowano jedynie trzy odłupki, które stanowiły przypuszczalnie element przygotowania pięty rdzenia.

W obrębie skupienia wydzielono dwa miejsca występowania krzemieni o zdiagnozowanych mikrośladach powstałych w wyniku prac. Pierwsze zawiera znaleziska

${ }^{4}$ Aspekty technologiczne zostały omówione w odrębnym artykule: T. Boroń, Rydno IV/47. Krzemienica kultury janisławickiej (cykl wiślański) (artykuł złożony do redakcji „Materiałów Archeologicznych”). 
was a calcinated trapeze (Fig. 12j) with minor damage on one of the side edges, the other a Wieliszew point (Fig. 12k). One of the four examined retouched blades (Fig. 12g) had been used to cut antler, another (Fig. 12h) for a hard material of some kind. As for the four examined retouched flakes, one was used for bone (Figs 12f; $13 \mathrm{~b}$ ), the other for an unspecified raw material (Fig. 12i). One of the 13 regular blades was used to cut plants and three for working some kind of soft material.

Animal carcass processing as well as processing of plants and wood were evidently the main activities taking place in the three concentrations. The tools used for the purpose were not intensively used as a rule. The nature of the use-wear traces on the scraping edges indicates scraping of fresh animal hides. The tools showing evidence on their edges of bone processing could be connected to animal carcass sectioning processes. Singular pieces with recorded evidence of cutting antler appear to reflect incidental actions and not regular approach to the processing of this raw material.

\section{SPATIAL DISTRIBUTION OF ACTIVITY AREAS}

Several blocks of two to five elements were refitted in the lab, most often pairs of flakes or platform rejuvenation flakes. Only three blocks illustrate a longer coring sequence: in one case, three flakes and a crested blade, in the second, a crested blade, endscraper, retouched flake and two raw flakes, and the third of a retouched flake and three rejuvenation flakes. ${ }^{4}$

Northern concentration. A spatial distribution of the flakes shows their concentration primarily in the southern part of the concentration (Fig. 14), together with all the rejuvenation flakes. Only three flakes, presumably coming from core-preparation, were refitted.

Two locations of flint artifacts with use-wear traces were recorded within this concentration. The first contains finds connected with wood preparation (flake products), the second with processing of animal bone, hides and plants (blade tools). Two singular products were also noted: a blade with evidence of cutting plants and a retouched blade for processing a soft raw material (Fig. 14).

$\mathrm{C}$ entral con ce ntration. A detailed planigraphy revealed two separate locations of an accumulation of blades and flakes. The former were generally concentrated on the fringes of the main concentration, in the northeastern and western sectors, that is, near where the microliths were recorded. The latter occupied the center and consisted almost exclusively of rejuvenation flakes.

Refitted blocks illustrate core preparation and rejuvenation (Fig. 15a) as well as preparation of a pre-flaking surface (Fig. 15b); they are proof of blade core exploitation taking place here. Most of the refitted finds came from the biggest grouping of flakes and rejuvenation flakes which could correspond to the location of the presu-

${ }^{4}$ Technological aspects have been discussed in a separate article: T. Boroń, Rydno IV/47. Krzemienica kultury janisławickiej (cykl wiślański) (submitted to "Materiały Archeologiczne"). 
związane z obróbką drewna (wytwory odłupkowe), drugie z obróbką kości, skór i roślin (narzędzia wiórowe). Odnotowano także dwa pojedyncze wytwory - jeden ze śladami cięcia roślin (wiór) i drugi obróbki miękkiego surowca (wiór łuskany) (ryc. 14).

Skupienie centralne. Na podstawie szczegółowej planigrafii stwierdzono, że w obrębie skupienia występują dwa oddzielne miejsca kumulacji wiórów i odłupków. Te pierwsze koncentrowały się generalnie na obrzeżach głównej koncentracji - w sektorze północno-wschodnim i zachodnim, a więc w pobliżu zlokalizowania mikrolitów. Natomiast odłupki zajmowały jej środkową część. Odnotowano tam także prawie wszystkie świeżaki.

Złożone bloki ilustrujące zaprawę i odnawianie pięty (ryc. 15a) oraz zaprawę odłupni (ryc. 15b) świadczą, że odbywała się tam eksploatacja rdzeni wiórowych. Większość dopasowanych znalezisk znajduje się w rejonie największego zgrupowania odłupków i świeżaków, co może sugerować obszar występowania domniemanej pracowni. Natomiast produkty rdzeniowania w postaci wiórów mogły być przeniesione do dwóch wyszczególnionych sektorów w celu wytwarzania narzędzi. Sieć składanek nie wykracza w zasadzie poza obręb skupienia.

Prawie wszystkie wytwory o zdiagnozowanych śladach pracy gromadziły się na obszarze największej kumulacji materiału. Występują tam narzędzia i wióry związane z przetwarzaniem skór, drewna, kości oraz cięcia i obróbki miękkiego i twardego surowca.

Następna strefa występowania krzemieni o rozpoznanych mikrośladach zlokalizowana jest w odległości dwóch metrów od głównej kumulacji (cięcie poroża oraz roślin).

Skupienie południowe. Dystrybucja przestrzenna wiórów i odłupków jest w miarę równomierna, a więc jest to odmienna sytuacja niż w przypadku powyżej opisanej. Składanka zatępca z trzema odłupkami (ryc. 16b) oraz dwóch odłupków pochodzących z odnawiania pięty (ryc. 16a) może wskazywać, że proces obróbki rdzeni miał tu również miejsce. Ze względu na brak wyraźnych kumulacji półsurowca, obróbka ta mogła mieć doraźny charakter. Linie składankowe

Ryc. 14. Rydno IV/47. Planigrafia wytworów określonych funkcjonalnie

a - rdzenie; b - drapacze; c - skrobacze; d - półtylczaki; e - zbrojniki typu Wieliszew; f - rylce; $\mathrm{g}$ - trapezy; $\mathrm{h}$ - nieokreślone formy mikrolitów; $\mathrm{i}$ - wióry łuskane; $\mathrm{j}$ - odłupki łuskane; $\mathrm{k}$ - inne; 1 - rylcowce; $\mathrm{l}$ - świeżaki; $\mathrm{m}$ - odłupki; $\mathrm{n}$ - wióry; o - zatępce; $\mathrm{p}$ - liczba wiórów na $\mathrm{m}^{2} ; \mathrm{r}$ - liczba odłupków na $\mathrm{m}^{2}$; $\mathrm{s}$ - linie składankowe; t - linie złamania. Oznaczenie kolorów: - obróbka skór; - obróbka kości/cięcie poroża; - obróbka/ cięcie drewna i roślin; - podział tuszy zwierzęcej; - cięcie twardego surowca; - obróbka miękkiego surowca; - obróbka nieokreślonego surowca.

Opracował T. Boroń

Fig. 14. Rydno IV/47. Planigraphy of functionally identified products

$\mathrm{a}$ - cores; $\mathrm{b}$ - endscrapers; $\mathrm{c}$ - scrapers; $\mathrm{d}$ - truncated blades; $\mathrm{e}$ - Wieliszew points; $\mathrm{f}$ - burins; $\mathrm{g}$ - trapezes; $\mathrm{h}$ - indeterminate microliths; $\mathrm{i}$ - retouched blades; $\mathrm{j}$ - retouched flakes; $\mathrm{k}$ - other; 1 - microburins; 1 - platform rejuvenation flakes; $\mathrm{m}$ - flakes; $\mathrm{n}$ - blades; $\mathrm{o}$ - crested blades; $\mathrm{p}$ - number of blades per $\mathrm{m}^{2} ; \mathrm{r}$ - number of flakes per $\mathrm{m}^{2}$; $\mathrm{s}$ - fitting lines; $\mathrm{t}$ - line of break. Color code: - animal hide processing; - bone processing/antler cutting; - processing/cutting of plants and wood; - animal carcass quartering; - cutting a hard raw material; $\bigcirc$ - cutting soft material;

- processing of indeterminate raw material.

Processing T. Boroń 


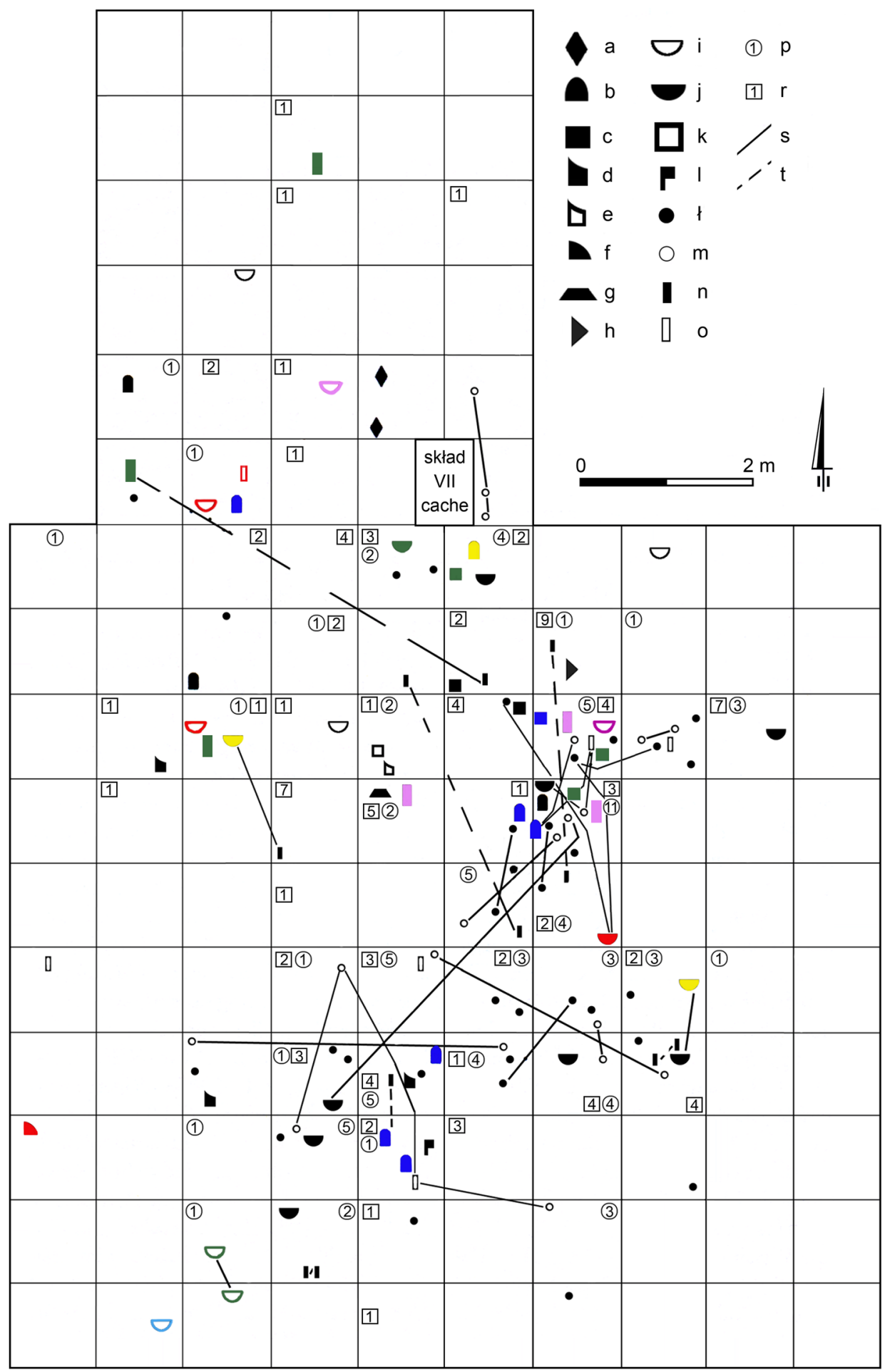


o wielokierunkowym przebiegu obejmują całą powierzchnię skupienia, co może dodatkowo potwierdzać powyższe sugestie odnośnie rdzeniowania.

Planigraficzny rozrzut w obrębie skupienia wyrobów określonych funkcjonalnie wykazał dwa ich zgrupowania. Jedno obejmowało drapacze związane z obróbką skór, zaś drugie stanowiły wióry łuskane powiązane z podziałem tuszy zwierzęcej i przetwarzaniem roślin. Poza odnotowanym rozplanowaniem wystąpiły także pojedyncze znaleziska wskazujące na pracę w kości (rylec) oraz obróbkę nieokreślonego surowca (odłupek łuskany).

W każdym ze skupień wyodrębniono strefę aktywności związaną z oczyszczaniem skór i podziałem tuszy zwierzęcej (ryc. 17). Znajdowały się one w pobliżu skupisk przepalonych kości zwierząt, zaś w skupieniu centralnym obok zgrupowania kamieni. Wymienione obiekty archeologiczne sugerują pozostałości osadnicze po istniejących tam ogniskach.

Natomiast najliczniejsze zgrupowanie znalezisk o stwierdzonych śladach mikrozniszczeń zanotowano w głównym miejscu kumulacji krzemieni w skupieniu centralnym. Jest to obszar aktywności obejmujący, poza wspomnianą już obróbką skór i podziałem tuszy zwierzęcej, także czynności związane z obróbką drewna oraz cięciem twardego i obróbką miękkiego surowca. Na podstawie złożonych bloków oraz sieci połączeń pomiędzy poszczególnymi elementami składanek, sektor ten jest również przypuszczalnie miejscem zaprawy i eksploatacji rdzeni (pracownia).

Pozostałe obszary pracy obejmują przetwarzanie roślin w skupieniu południowym oraz obróbkę drewna w skupieniu północnym (ryc. 17), zaś występowanie pojedynczych okazów świadczy przypuszczalnie o incydentalnym działaniu.

\section{UWAGI KOŃCOWE}

Na podstawie analizy przestrzennej wydzielono w krzemienicy trzy skupienia: północne, centralne i południowe. Są one niewątpliwie pozostałościami po rozlokowanych obozowiskach o statusie łowieckim z elementami aktywności podomowej (obróbka rdzeni, produkcja narzędzi).

Zważywszy na niezbyt liczny inwentarz krzemienny, w szczególności sporadyczne występowanie mikrolitów, można domniemywać, że były one dość krótkotrwałe. Wydaje się również, że pewnym podkreśleniem tymczasowości obozowisk są dość zawężone przestrzennie strefy aktywności. W przypadku obozowisk o znaczniej dłuższym epizodzie osadniczym następuje rozszerzenie eksploatowanych sektorów, co widać na przykładzie wielu innych stanowisk (Juel Jensen, Brinch Petersen 1985, s. 49; Osipowicz 2015, s. 77; Souffi i in. 2015, s. 753).

Każde z wyszczególnionych obozowisk reprezentuje odrębne wydarzenie osadnicze, a potwierdzeniem powyższej tezy jest zbliżony typologicznie inwentarz krzemienny w każdym z nich, o zachowanych proporcjach ilościowych pomiędzy poszczególnymi klasami narzędzi. Następnie, wykonywanie tych samych czynności określoną grupą wytworów (ryc. 18), a przede wszystkim zarejestrowana aktywność podziału tuszy zwierzęcej. Występuje również podobna organizacja przestrzeni ze 
med workshop. Blades from the core exploitation process could have been moved to the specified sectors to produce tools. The refitting pattern does not exceed the boundaries of the concentration as a whole.

Almost all the products with use-wear traces were found within the biggest grouping of finds. They include tools and blades used for processing animal hides and bone, wood and some kind of soft and hard material that was cut and treated.

The other zone with flint demonstrating use for cutting antler and plants occurs $2 \mathrm{~m}$ from the main accumulation.

S o u the r n con ce nt r at i o n. The spatial distribution of blades and flakes is fairly even, unlike the situation in the central concentration discussed above. A refitting of a crested blade with three flakes (Fig. 16b) and of two flakes from a platform rejuvenation (Fig. 16a) indicates that core preparation was an activity here as well. It must have been a short-term affair as there is no accumulation of half-products to speak of. Refitting lines going in many different directions cover the entire surface of the concentration, reinforcing the suggestion concerning core exploitation.

Two groups of artifacts with functionally identified use-wear traces were demonstrated by a planigraphic distribution of the finds. One of these was a set of endscrapers for animal hide processing, the other retouched blades for animal carcass butchering and plant processing. Singular finds outside these groups indicated working in bone (burin) and processing of an unidentified raw material (retouched flake).

An activity zone connected to processing animal hides and butchering animal carcasses was identified in every one of the concentrations (Fig. 17). In each case, it was found near concentrations of burnt animal bones and in the central concentration there was additionally a cluster of stones near this zone. These archaeological features suggest the presence of camp fires.

A cluster with the most numerous set of finds demonstrating use-wear traces was recorded at the densest grouping of flint artifacts in the central concentration. This zone of activity would have included, beside the said animal hide processing and carcass sectioning, also treating wood and cutting and processing of some kind of soft raw material. Block refittings and the relation network between the refitted pieces lead to the identification of this spot as a workshop area for preparing and exploiting cores.

The remaining work areas can be identified as a plant processing zone in the southern concentration and wood processing in the northern concentration (Fig. 17). The occurrence of singular pieces should be seen as proof of incidental actions.

\section{FINAL REMARKS}

Spatial analysis led to three concentrations being distinguished: northern, central and southern. All three are undoubtedly remains of campsites established by hunters engaged in certain aspects of domestic activities (core preparation, tool production).

In view of the not extensive flint inventory, especially the sporadic presence of microliths, these campsites should be presumed to have been rather short-lived. The 

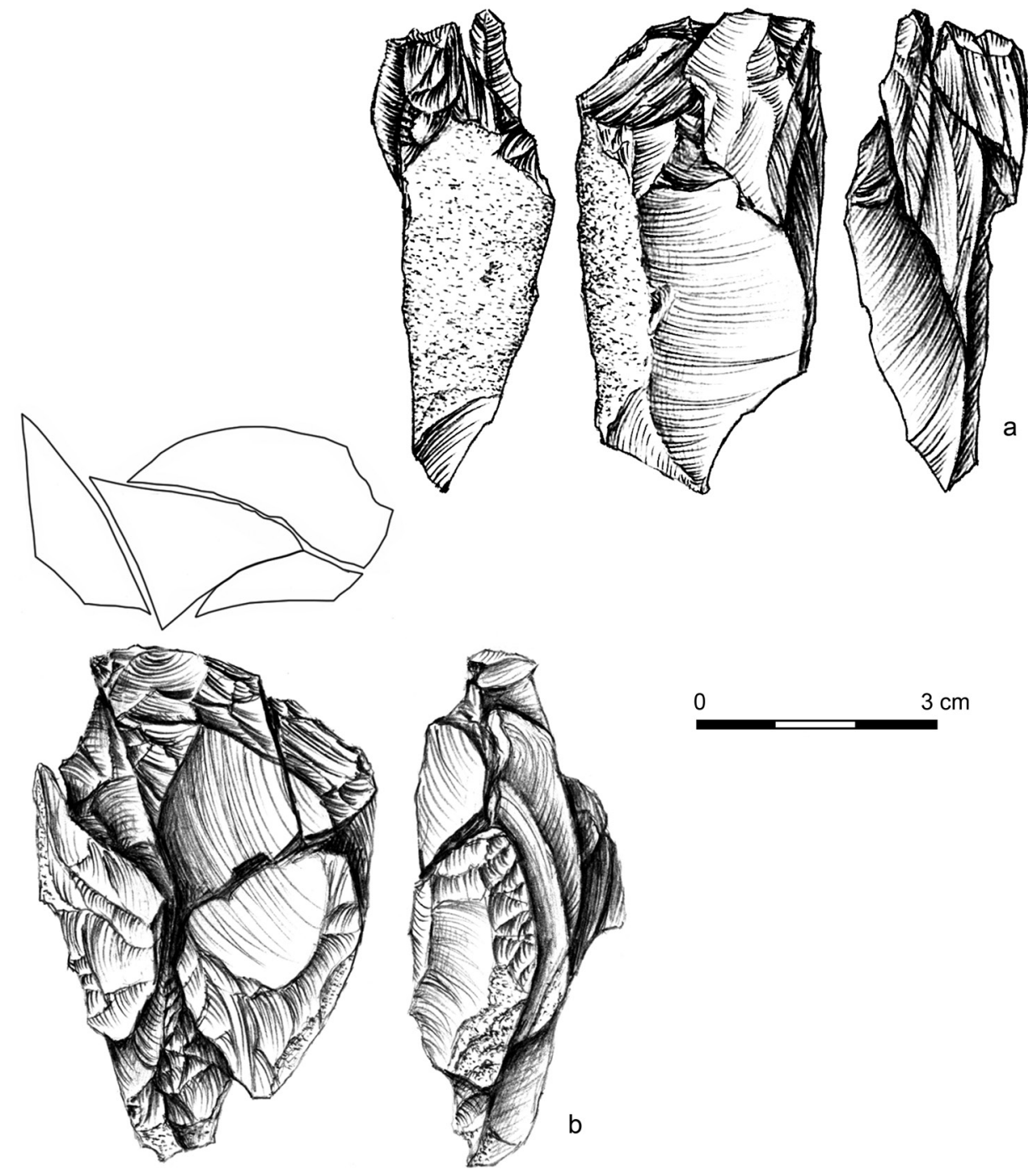

Ryc. 15. Rydno IV/47. Skupienie centralne

a - składanka świeżaków i odłupka łuskanego; b - składanka zatępca z drapaczem, odłupkiem łuskanym i odłupkami.

Rys. E. Gumińska

Fig. 15. Rydno IV/47. Central scatter

a - refitting of platform rejuvenation flakes and retouched flake; b - refitting of crested blade and endscraper, retouched flake and flakes. 

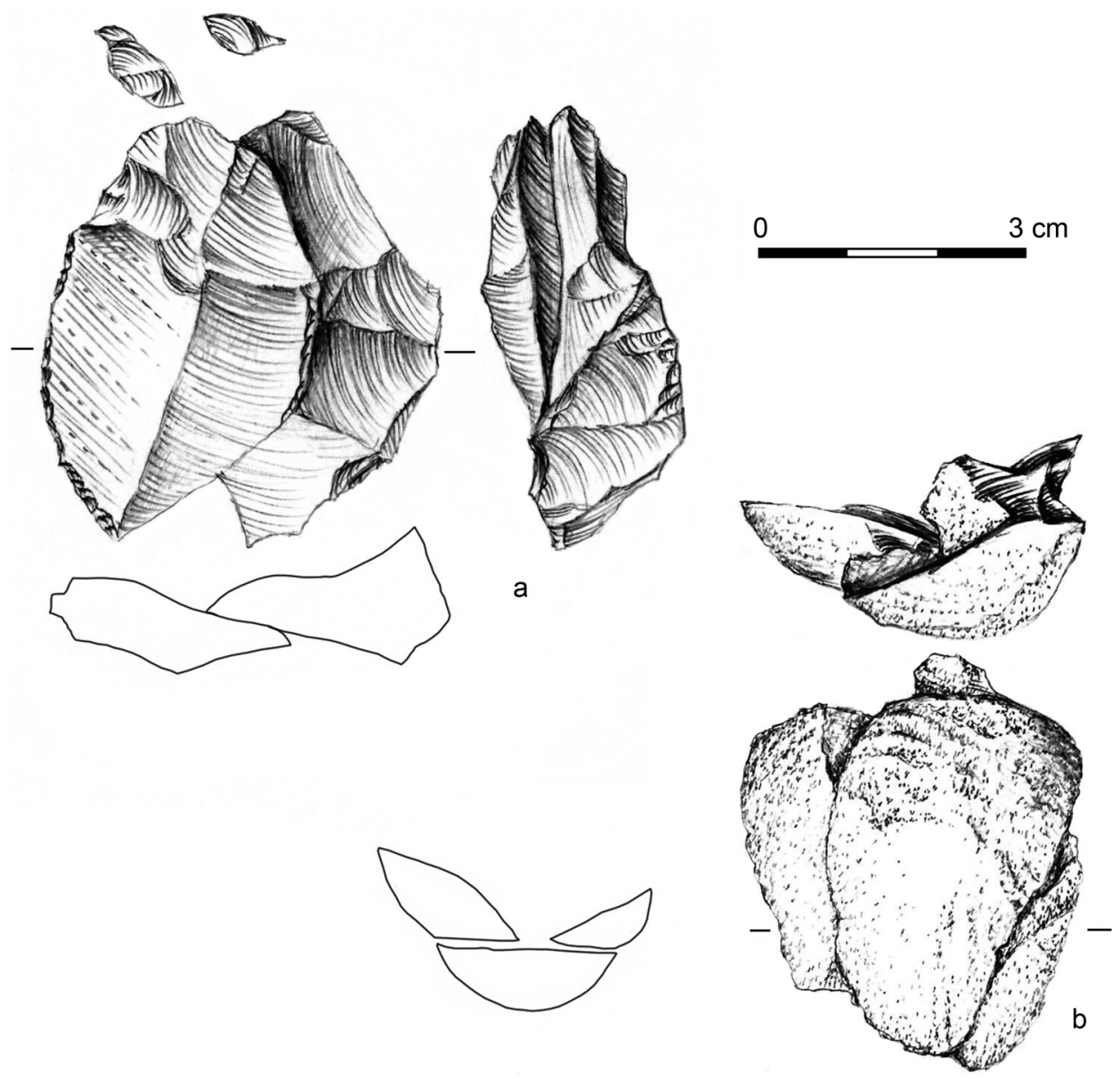

Ryc. 16. Rydno IV/47. Skupienie południowe

a - składanka odłupków łuskanych pochodzących z odnawiania pięty; b - składanka zatępca $\mathrm{z}$ odłupkami.

Rys. E. Gumińska

Fig. 16. Rydno IV/47. Southern scatter

a - refitting of retouched flakes from rejuvenation of a striking platform; b - refitting of crested blade and flakes. Drawing E. Gumińska

narrowed activity zones may also be an indication of the provisional nature of these campsites, which would have exhibited extensions of the exploited sectors had they lasted any length of time. There are many examples of such long-lived camps (Juel Jensen, Brinch Petersen 1985, p. 49; Osipowicz 2015, p. 77; Souffi et al. 2015, p. 753).

Each of the three campsites represents a separate occupation event, indicated by the typologically similar flint inventory preserving quantitative proportions between specific tool classes. Moreover, the same activities were undertaken in all three spots using a specific set of tools (Fig. 18) and in all three instances animal carcass 


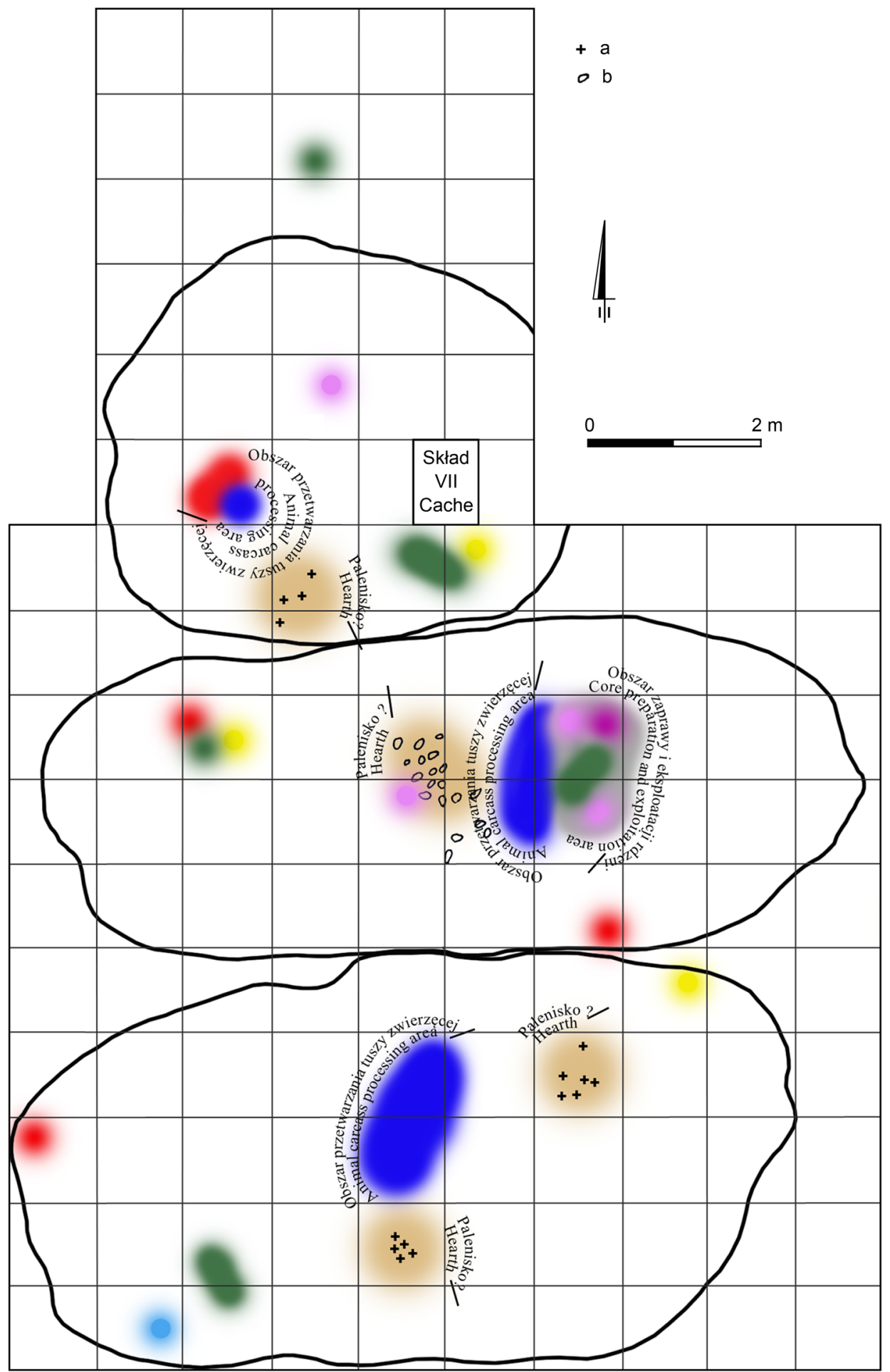




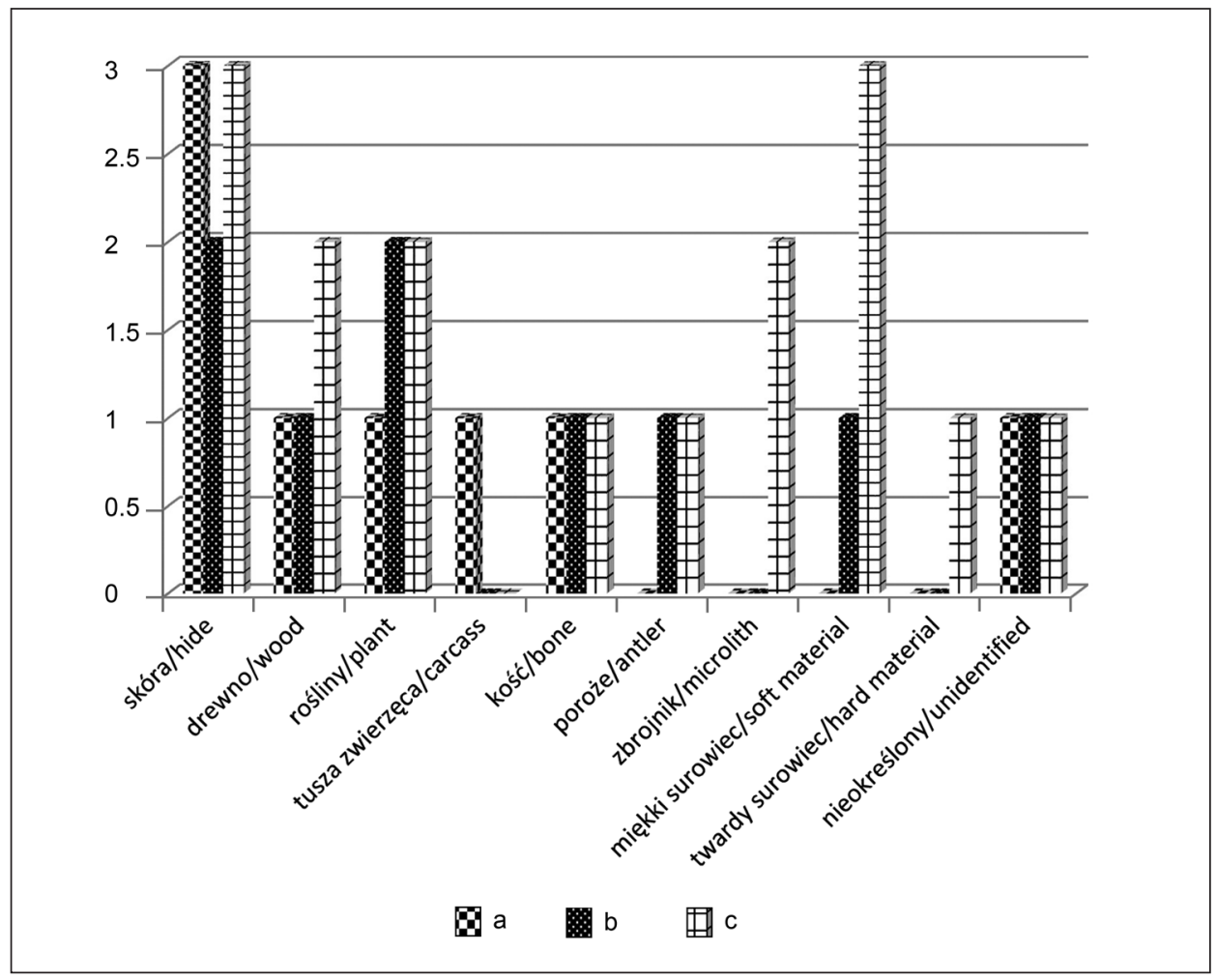

Ryc. 18. Rydno IV/47. Frekwencja narzędzi ze śladami obróbki różnych surowców a - skupienie południowe; b - skupienie północne; c - skupienie centralne.

Opracowała M. Winiarska-Kabacińska

Fig. 18. Rydno IV/47. Frequency of tools with traces of use-wear processing different raw materials a - southern scatter; b - northern scatter; $c$ - central scatter.

Processing M. Winiarska-Kabacińska

Ryc. 17. Rydno IV/47. Graficzne modelowanie obszarów aktywności a - przepalone kości; b - kamienie.

Opracowała A. Sołodko

Fig. 17. Rydno IV/47. Graphic modeling of areas of activity $\mathrm{a}$ - burnt bones; $\mathrm{b}$ - stones. 
szczególnym uwzględnieniem miejsca oprawiania zwierząt, które stanowiło niewątpliwie główne centrum każdego z obozowisk, zaś inne czynności były rozproszone na znacznym obszarze.

Zdefiniowana rozmaitość wykonywanych działań na stanowisku Rydno IV/47, jak również obrabianych surowców, jest w zasadzie typowa dla społeczności mezolitycznych, zaś różnice wynikają jedynie z ich natężenia i intensywności (Lemorini 1992, s. 56; Hardy 1999; Hardy, Svoboda 2009, s. 166; Crombé, Beugnier 2013, s. 180; Mazzucco i in. 2016, s. 155; Boroń, Winiarska-Kabacińska 2018, s. 162). Czasami jednak realizowane czynności $\mathrm{w}$ obozowiskach mezolitycznych wydają się być znacznie uboższe (Lemorini 1992, s. 54; taż 1997, s. 50; Petru 2004, s. 201-203).

Obserwacje traseologiczne poczynione na materiale krzemiennym z Rydna potwierdzają dotychczasowe wnioski, że obróbka surowca roślinnego odbywała się za pomocą narzędzi wiórowych (Beugnier, Crombé 2005, s. 537; Guéret i in 2014, s. 7).

W literaturze przedmiotu krzemienica IV/47 określona jest mianem „middle-sized flint processing workshop" (Schild i in. 2011, s. 351). Oczywiście, rozpatrując całościowo zbiór materiału, jest to określenie zasadne. Jednakże uwzględniając wyniki analizy funkcjonalnej, jak również przestrzennej, zredefiniowano jej znaczenie. Analizowane zabytki w aspekcie funkcjonalnym wydobyte na stanowisku Rydno VI/60 poświadczają dominację obróbki drewna i roślin (Boroń i in. 2018), natomiast te ze stanowiska Rydno IV/47 pokazują przede wszystkim, że skupiano się na rozdziale tuszy zwierzęcej, przy obecności innych czynności. Te ostatnie obozowiska są więc funkcjonalnie dużo bardziej zróżnicowane, będąc najpewniej miejscem, w którym przetwarzano upolowaną zwierzynę. Być może czynnikiem, który mobilizował grupy łowców mezolitycznych do ponownych powrotów, była nie tylko eksploatacja i pozyskiwanie hematytu z pobliskiej kopalni, ale także sprzyjające tereny myśliwskie.

Przeprowadzone studia przestrzenno-funkcjonalne osadnictwa mezolitycznego kultury janisławickiej oparte na materiałach z dwóch wymienionych wcześniej stanowisk wykazały istotne różnice między nimi, pomimo braku mikrolitów w obydwu inwentarzach, nie licząc trzech okazów, w tym dwóch zniszczonych, z Rydna IV/47. W literaturze przedmiotu panuje powszechny i akceptowany pogląd, że termin „krótkotrwałe obozowisko łowieckie" jest zarezerwowany dla specyficznych stanowisk, których inwentarze zawierają także mikrolity. Jak wynika z osiągniętych rezultatów, termin ten jest też adekwatny dla obozowisk o nieco innej strukturze narzędziowej. 
sectioning was recorded. The organization of space is also the same in all three concentrations: a place for skinning dead animals at the center of each concentration and other activities scattered around over a larger area.

The range of activities observed at the Rydno IV/47 site, as well as the variety of processed raw materials, is basically typical of Mesolithic communities, the differences lying mainly in intensity (Lemorini 1992, p. 56; Hardy 1999; Hardy, Svoboda 2009, p. 166; Crombé, Beugnier 2013, p. 180; Mazzucco et al. 2016, p. 155; Boroń, Winiarska-Kabacińska 2018, p. 162). It seems, however, that these activities in Mesolithic camps seem to have been much poorer overall sometimes (Lemorini 1992, p. 54; Lemorini 1997, p. 50; Petru 2004, pp. 201-203).

Traseological studies of the flint material from Rydno has also confirmed earlier suggestions that blade tools were used to process plant resources (Beugnier, Crombé 2005, p. 537; Guéret et al. 2014, p. 7).

The Rydno IV/47 concentration has been described in the literature as a "middle-sized flint processing workshop" (Schild et al. 2011, p. 351). Overall, the description is justified, but from the point of view of both the functional and the spatial analysis, its significance should be redefined. A functional approach to finds from Rydno VI/60 confirm the predominance of wood and plant processing (Boron et al. 2018), whereas the finds from Rydno IV/47 demonstrate butchering to be the primary activity, accompanied by other activities. Thus, the latter campsites are much more differentiated functionally and were most probably places where the hunted animals were processed. Perhaps the reason why groups of Mesolithic hunters returned to the place was not just the exploitation of hematite from the nearby mine, but also good hunting grounds.

Studies of spatial organization and functionality of Mesolithic settlement of the Janisławice culture on the grounds of material from the two sites mentioned above have demonstrated significant differences between them, despite an absence of microliths in the two inventories, if one omits the three pieces, two of which are damaged, from Rydno IV/47. It is commonly accepted in scholarly circles that the term "short-lived hunting campsites" is reserved for sites with microliths in their inventories. As indicated by the results of the present study, the term is justified also with regard to campsites presenting a slightly different tool structure. 


\section{WYKAZ CYTOWANEJ LITERATURY}

\section{BIBLIOGRAPHY OF WORKS CITED}

B e u g n i e r V., C r o m b é P. 2005, Étude fonctionelle du matériel en silex du site mésolithique ancien de Verrebroek (Flandres, Belgique): premiers résultats, „Bulletin de la Société Préhistorique Française", 102, pp. 527-538.

B o r o ń T., W i n i a r s k a-Ka b a c i ń sk a M. 2018, Late Mesolithic settlements from the area of Mazovia (Kokry Industry), Spatial-functional camp interpretations, „Archäologisches Korrespondenzblatt", 48, pp. 153-176.

B oroń T., Winiar ska-Kabacińska M., Sołodko A. 2018, Rydno VI/60. Wyspecjalizowane obozowisko społeczności mezolitycznej kultury janisławickiej, Sum.: Rydno VI/60. Specialized campsite of a Mesolithic Janisławice culture community, „Archeologia Polski”, 63 , pp. 29-46.

C r o m b é P., B e u g n i e r V. 2013, La fonction des industries en silex et les modalities d'occupation des territoires au Mésolithique. Le cas des zones sableuses du nord-ouest de la Belgique et des Pays-Bas (8700-5400 cal. BC), „L'Anthropologie”, 117, pp. 172-194.

F i e d o r c z u k J. 1992, Późnopaleolityczne zespoly krzemienne ze stanowiska Rydno IV 57 $w$ świetle metody składanek, Sum.: Late Palaeolithic flint assemblages from the Rydno IV 57 site in the light of the refitting method, „Przegląd Archeologiczny”, 39, pp. 13-65.

G i n t e r B. 1965, Dwie krzemienice mezolityczne z Grzybowej Góry, pow. Starachowice (Rydno), Rés.: Deux stations de silex mésolithiques de localité Grzybowa Góra (Rydno), district Starachowice, „Materiały Archeologiczne”, 6, pp. 5-32.

G r ø $\mathrm{n}$ O. 1995, The Maglemose culture. The reconstruction of the social organization of a mesolithic culture in Northern Europe, BAR International Series, 616, Oxford.

$\mathrm{Gr} ø \mathrm{n}$ O. 2003, Mesolithic dwelling places in south Scandinavia thief definition and social interpretation, „Antiquity”, 77, pp. 685-708.

Guér et C., G a s s in B., Ja c qu i e r J., M a r ch and G. 2014, Traces of plant working in the Mesolithic shell midden of Beg-an-Dorchenn (Plomeur, France), „Mesolithic Miscellany", 22, pp. 3-15.

H a r d y B. L. 1999, Preliminary results of residue and use-wear analyses of stone tools from two Mesolithic sites, northern Bohemia, Czech Republic, "Archeologické rozhledy”, 51, pp. 274-279.

H a r d y B. L., S v o b o d a J. A. 2009, Mesolithic stone tool function and site types in Northern Bohemia, Czech Republic, [in:] Archaeological science under a microscope studies in residue and ancient DNA analysis in honour of Thomas H. Loy, M. Haslam, G. Robertson, A. Crowther, S. Nugent, L. Kirkwood eds., Terra Australis, 30, Canberra, pp. 159-174.

Juel J e n se n H., B r in ch Pet e r s e n E. 1985, A functional study of lithic from Vonget Nord, a Mesolithic site at Vedboek, N.E. Sjoelland, "Journal of Danish Archaeology”, 4, pp. $40-51$.

Kobyliński Z. 1987, Podstawowe metody analizy punktowych układów przestrzennych, Sum.: Basic methods for analysis of spatial point patterns, „Archeologia Polski”, 32/1, pp. 21-53.

Krukowski S. 1939-1948, Paleolit, [in:] Prehistoria ziem polskich, Kraków, pp. 1-117.

L e mor in i C. 1992, Etude fonctionnelle des industries mésolithiques de Lago delle Buse 1 et Lago delle Buse 2 (Lagorai, Trentino) par la méthode des traces d'utilistion, „Preistoria Alpina”, 28, pp. 51-59. 
L e m o r in i C. 1997, A functional approach through trace wear analysis, [in:] Excavations at the high altitude mesolithic site of Laghetti del Crestoso (Bovegno, Brescia - Northern Italy), C. Baroni, P. Biagi eds., Brescia, pp. 48-57.

Mazzucco N., Gibaja Bao J.F., Perales Barrón U., Millán Lo mas M.S., García Puchol O., Rojo Guerra M., Royo Guillén J.I., Martínez de Lagrán I. G., C a ba nille s J. J., G a z ol a z J. G., G a s s in B. 2016, Insights into the Late Mesolithic toolkit: use-wear analysis of the notched blades. Case-studies from the Iberian Peninsula, „Preistoria Alpina”, 48, pp. 151-157.

O s i p o w ic z G. 2015, Zorganizowane i wyspecjalizowane obozowisko zbieraczy? Z wyników badań traseologicznych i przestrzennych materiałów mezolitycznych ze stanowiska Ludowice 6, Sum.: Organized and specialized camp of gatherers? From the results of use-wear and spatial analyze of the Mesolithic sources from site Ludowice 6, „Przegląd Archeologiczny”, 63 , pp. 59-85.

P e t r u S. 2004, Use wear analysis of Mesolithic and Neolithic stone tools from Mala Triglavca, Trhlovca and Pupičina peć, „Documenta Praehistorica”, 31, pp. 199-204.

S a w i c k i L. 1935, Przemysł świderski I stanowiska wydmowego Świdry Wielkie I, „Przegląd Archeologiczny", 5/1, pp. 1-23.

S c h ild R. 1967, Wieloprzemystowe stanowisko Rydno IV/57 (Grzybowa Góra) pow. Starachowice, Rés.: Rydno IVI57 - Station du paléolithique final et du mésolithique, [in:] Materiały do prahistorii plejstocenu i wczesnego holocenu Polski, W. Chmielewski ed., Wrocław-Warszawa-Kraków, pp. 124-207.

S child R. 1980, Introduction to dynamic technological analysis of chipped stone assemblages, [in:], Unconventional archaeology. New approaches and goals in Polish archaeology, R. Schild ed., Wrocław-Warszawa-Kraków-Gdańsk, pp. 57-85.

S ch ild R. 1990, The mystery of the Desna - type assemblages in Poland, [in:] Contributions to the Mesolithic in Europe, P.M. Vermeersch, P. Van Peer eds., Leuven, pp. 299-304.

S ch ild R., K rólik H. 1981, Rydno. A Final Paleolithic ochre mining complex, „Przegląd Archeologiczny", 29, pp. 53-97.

Schild R., Królik H., Tomaszewski A. J., Ciepielewska E. 2011, Rydno. A Stone Age red ochre quarry and socioeconomic center. A century of research, Warsaw.

S child R., Marczak M., Królik H. 1975, Późny mezolit. Próba wieloaspektowej analizy otwartych stanowisk piaskowych, Sum.: The Late Mesolithic. An example of multiaspectual analysis of open air sites from sandy lowlands, Wrocław-Warszawa-Kraków-Gdańsk.

S ouffi B., Guéret C., Griselin S., Guille mard I., Le duc C. 2015, Le site mésolithique de Rosnay "Haut-de-Vallière» (Marne). Une occupation spécialisée du premier Mésolithique, „Bulletin de la Société Préhistorique Française”, 112, pp. 717-759.

S t a p e $\mathrm{t}$ D. [1989] 1991, The ring and sector method: intrasite spatial analysis of stone age site with special reference to Pincevent, „Paleohistoria”, 31, pp. 1-57.

S t a p e r t D. 1992, Rings and sectors: Intrasite spatial analysis of Stone Age sites, Groningen.

To m a s z e w ski A. J. 1986, Metoda składanek wytworów kamiennych i jej walory poznawcze, Sum.: The method of refittings of chipped stone artefacts and its research value, „Archeologia Polski”, 31/2, pp. 239-273.

Tomaszewski A.J., Królik H., Ciepielewska E., Mańka D. 2008, Kto inny, kiedyindziej, na drugim brzegu. Różnice w wykorzystaniu krzemienia czekoladowego w niektórych zespołach późnopaleolitycznych, Sum.: Somebody else, another time on the opposite side of the river. Differences in the use of chocolate flint in same Final palaeolithic assemblages at Rydno, [in:] Krzemień czekoladowy w pradziejach. Materiały z konferencji w Orońsku, 08-10.10.2003, W. Borkowski, J. Libera, B. Sałacińska, S. Sałaciński eds., Warszawa-Lublin, pp. 379-397. 
